\title{
Community-Based Methods for Monitoring Coastal Erosion
}

A step-by-step guide for documenting shoreline change in your community
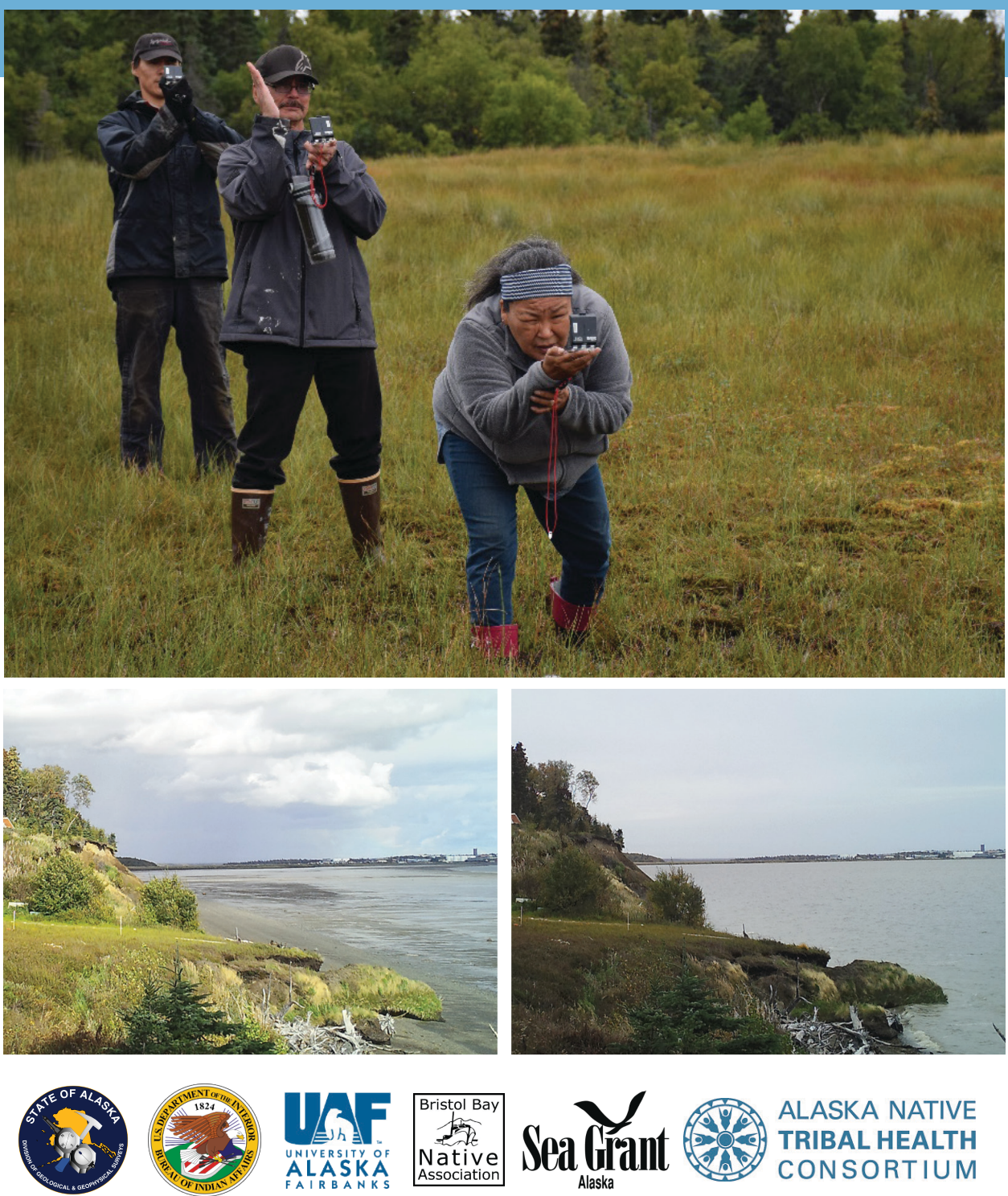

ISF UNIVERSITY OF ALASKA EAIRBANKS
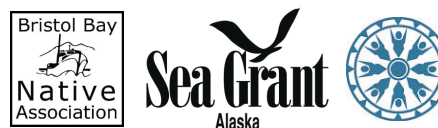

ALASKA NATIVE TRIBAL HEALTH CONSORTIUM 


\section{STATE OF ALASKA}

Michael J. Dunleavy, Governor

\section{DEPARTMENT OF NATURAL RESOURCES}

Corri A. Feige, Commissioner

\section{DIVISION OF GEOLOGICAL \& GEOPHYSICAL SURVEYS}

Steve Masterman, State Geologist and Director

Publications produced by the Division of Geological

$\&$ Geophysical Surveys (DGGS) are available for free download from the DGGS website (dggs.alaska.gov).

Publications on hard-copy or digital media can be examined or purchased in the Fairbanks office:

Alaska Division of Geological \& Geophysical Surveys 3354 College Rd., Fairbanks, Alaska 99709-3707

Phone: (907) 451-5010 Fax (907) 451-5050

dggspubs@alaska.gov|dggs.alaska.gov

DGGS publications are also available at:

Alaska State Library

Historical Collections \& Talking Book Center

395 Whittier Street

Juneau, Alaska 99811

Alaska Resource Library and Information Services (ARLIS)

3150 C Street, Suite 100

Anchorage, Alaska 99503

\section{Suggested citation:}

Buzard, R.M., Overbeck, J.R., and Maio, C.V., 2019, Communitybased methods for monitoring coastal erosion: Alaska Division of Geological \& Geophysical Surveys Information Circular 84, $35 \mathrm{p}$. 


\section{COMMUNITY-BASED METHODS FOR MONITORING COASTAL EROSION}

Richard Buzard ${ }^{1}$, Jacquelyn Overbeck ${ }^{1}$, and Christopher Maio²

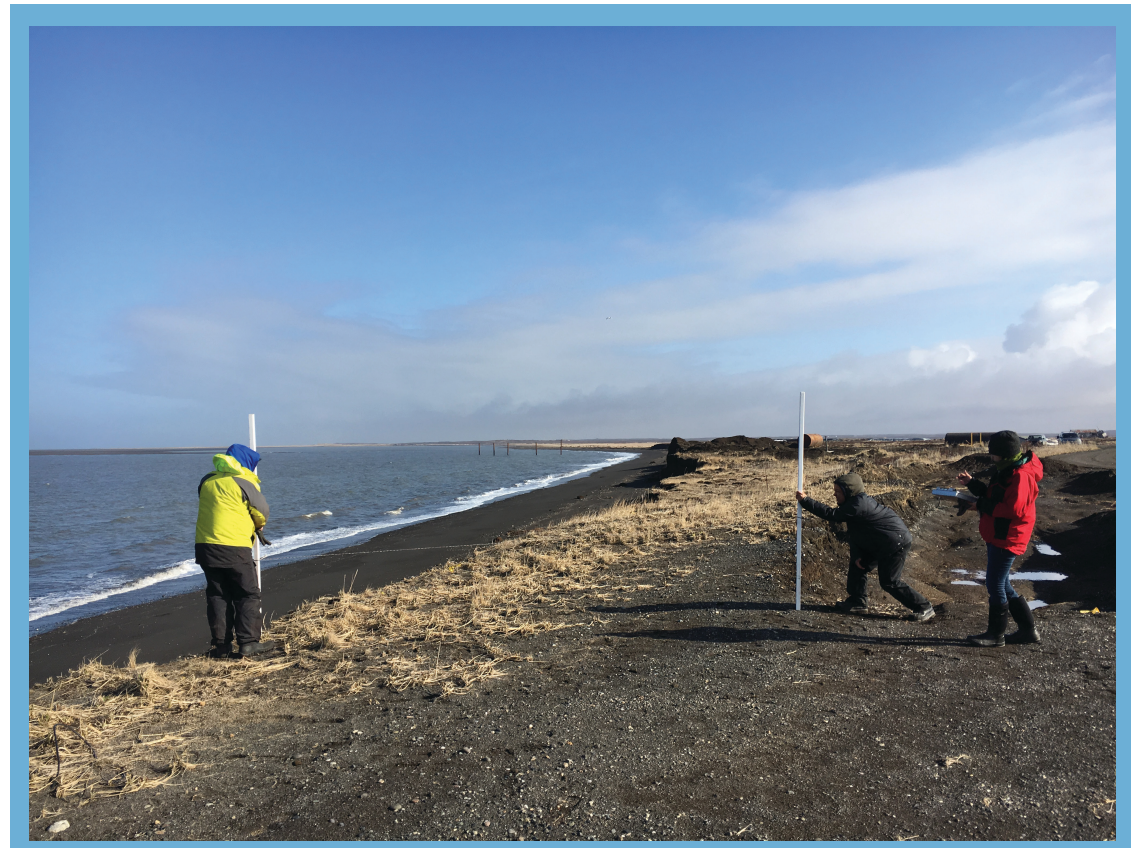

Port Heiden residents measuring erosion and topographic changes using Emery Rods.

${ }^{1}$ Alaska Division of Geological \& Geophysical Surveys, 3354 College Road, Fairbanks, AK, 99709-3707; richard.buzard@alaska.gov and jacquelyn.overbeck@alaska.gov

${ }^{2}$ University of Alaska Fairbanks, Department of Geosciences, PO Box 755780, Fairbanks, AK, 99775; cvmaio@alaska.edu 


\section{CONTENTS}

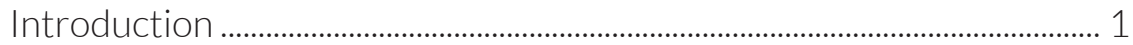

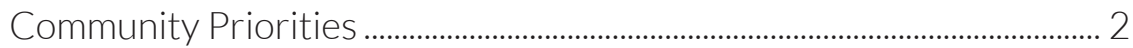

Select a Monitoring Site ……………………………………………………….... 3

Select a Monitoring System .................................................................................... 4

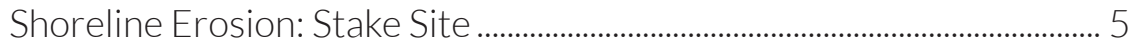

Shoreline Erosion: Stake and Camera Site .................................................... 11

Beach Erosion: Cross-Shore Profile Site _........................................................ 17

Equipment Maintenance/Inventory ……………………………………….... 25

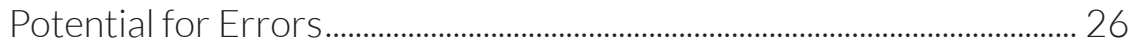

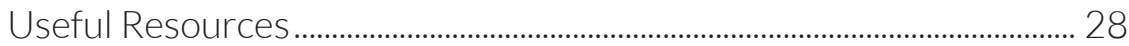

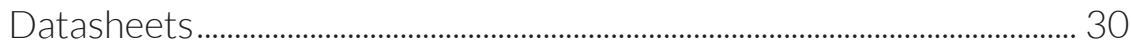

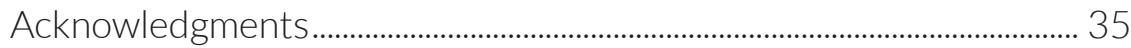

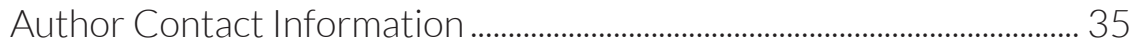




\title{
INTRODUCTION
}

This booklet provides comprehensive instructions for implementing three community-based shoreline monitoring systems, with all instructions designed to be completed by local residents. Tips for selecting monitoring sites, instructions for site installation and data collection, and all necessary materials are explained in a step-by-step format. By building an understanding of long-term shoreline change, Alaskans will be better prepared to respond and adapt to impacts to their public health, safety, infrastructure, and well-being.

The majority of rural Alaskan communities are located near oceans, rivers, and lakes, and many are particularly vulnerable to shoreline change.

\section{"I lost a subsistence site that was over 100 feet back because of erosion. We had to pull our set nets because of islands of land floating by."}

-Resident, Pilot Point

\begin{abstract}
"We have land along the river that has been piling up and now there are trees developing. The river is getting more difficult for the barge to navigate."
\end{abstract}

-Resident, New Stuyahok

Currently, the effects of shoreline change in Alaska are not well documented, due in part to the expansive coastline and lack of monitoring equipment in rural areas.

The goal of this booklet is to equip local observers with the training and tools to methodically document erosion-prone coastal areas. With the help of community-based monitoring, we can build local capacity to document the changes and communicate concerns using scientific methods.

\section{"This was good timing as I didn't have a plan on how to monitor other than take photos and notes.} Simple, easy to use!" 


\section{COMMUNITY PRIORITIES}

Ensure that shoreline monitoring is important to your community. It is important to get input from your community before beginning a shoreline monitoring project. The more people who know about your project, the more ideas and assistance you are likely to receive throughout the process. Community awareness may also reduce the likelihood of vandalism and accidental removal of site equipment.

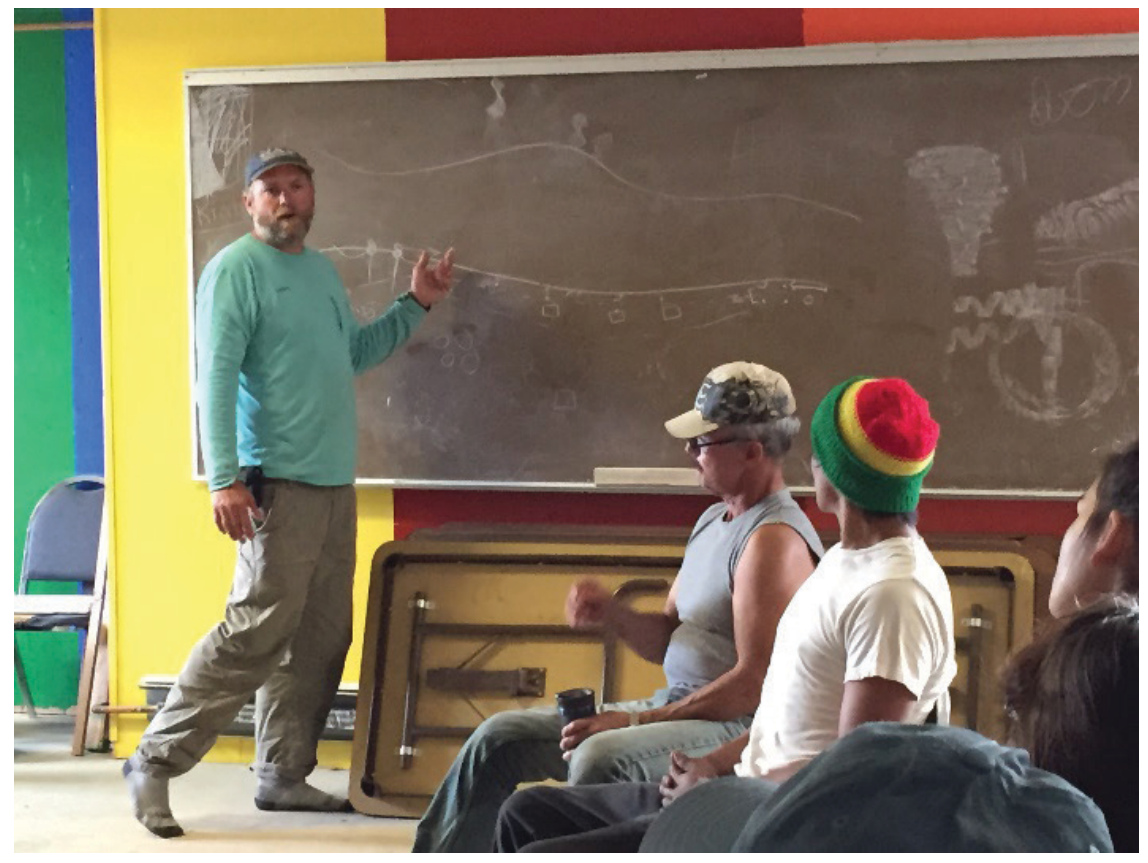

Determining which sites are most important for your community to monitor may require asking Elders, hunters, and local government for their opinion.

Determine land ownership and make sure to get permission to monitor at a site before you begin. This may involve getting permits or asking the property owner or Tribal Council for permission. You might consider presenting shoreline monitoring at a community meeting to get these conversations started. 


\section{SELECT A MONITORING SITE}

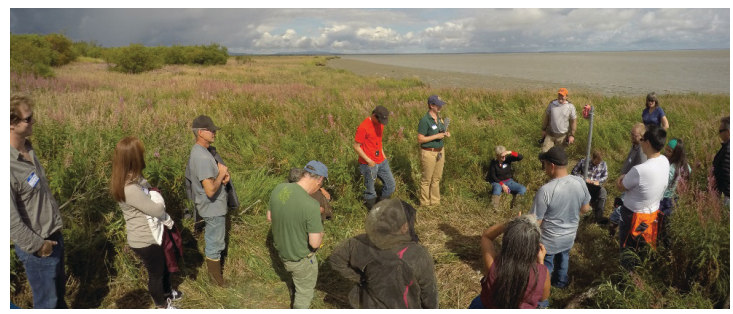

There are many factors that make a location suitable for shoreline monitoring. Consider some of the following when selecting your monitoring sites:

- The location should be vulnerable to erosion-for example, some areas erode when fall storms occur-otherwise there will be no changes to monitor.

- Consider how seasonal changes may affect the site. Is it accessible year round?

- Balance accessibility with risk of damage to the site. Keep it far from foot/vehicle traffic, but close enough where you can collect data with relative ease.

- If setting up a camera, look for areas with good visibility and low brush.

- Consider your safety. Take into account ledges, uneven or unstable ground, nearby firearm activity, wildlife, etc., before deciding on a site. Make sure the site will remain safe to navigate in winter conditions.

- Get necessary permissions or permits to use the site.

A good example of a site is the eroding bluff in Dillingham near the local sewage lagoon. The sewage lagoon is vital infrastructure for Dillingham, the property is fenced off to limit public access, vegetation is low near the shoreline, and erosion occurs often. One drawback of this site is local bear traffic - see if you can spot the bear!

\&

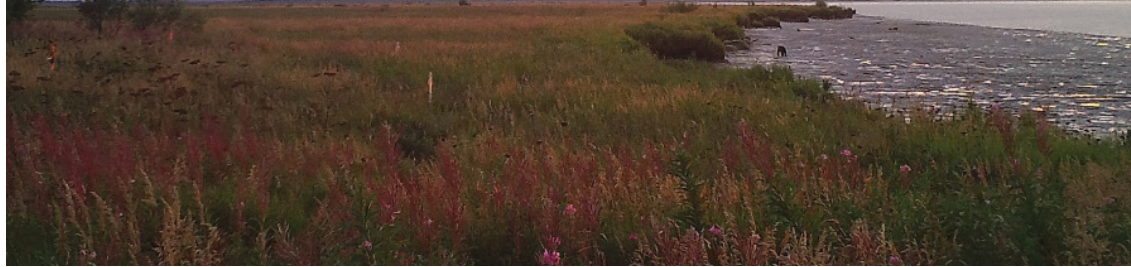




\section{SELECT A MONITORING SYSTEM}

There are three monitoring methods described in this booklet:

- Shoreline erosion: Stake site

- Shoreline erosion: Stake and camera site

- Beach erosion: Cross-shore profile site

Each system has advantages and disadvantages that should be considered before implementation. That said, the more monitoring methods you use, the stronger your knowledge of shoreline change in your community will be, and the better positioned you will be to make decisions about mitigating shoreline change impacts.

See the following pages for step-by-step instructions for each of the three monitoring systems. 


\section{SHORELINE EROSION: STAKE SITE}

\section{Required Materials:}

- Fixed reference markers (stakes or infrastructure)

- Measuring tape

- Compass

- Camera for site photos

- Data sheet
The shoreline is a feature that represents the land/water interface of an ocean, lake, or river. The shoreline could be the edge of vegetation, a scarp, or the edge of a bluff. Because the shoreline is changing, the simplest method for monitoring this change is to measure it from a permanent site nearby.

You can install two stakes into the ground to make a permanent site, or use a nearby structure if available. As long as you can consistently measure from a fixed point to the shoreline, it can be used as a shoreline change monitoring site. To keep consistent measurements, install stakes to create an imaginary line pointing to the shoreline. Take measurements along this line.

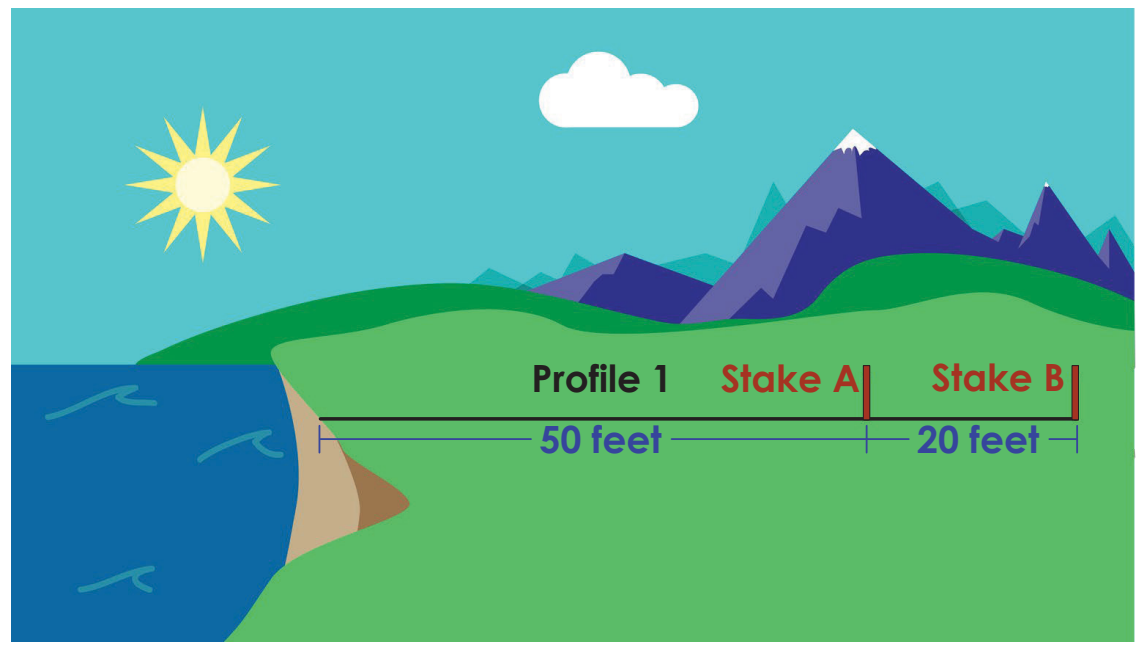

In this example, you can measure from stake A to the bluff edge along the imaginary line connecting both stakes. 


\section{Installation:}

Once you have determined a monitoring site, plan to install at least two profiles at the site. A profile is the imaginary line perpendicular to the coast on which you will measure change.

\section{For each profile:}

1. Place the first stake about 25-50 feet from the eroding feature. If erosion is particularly fast, you may consider installing the site further away.

2. Place the second stake about 10-20 feet landward from the first stake. Make sure to stay perpendicular to the shoreline.

3. Record your installation. Label the profile by number (profile 1, profile 2, etc.). Label the stakes by letter (A, B, C, etc.). Have stake A closest to the coast, so you have more letters that you can use at the site in the future if stakes are lost to erosion.

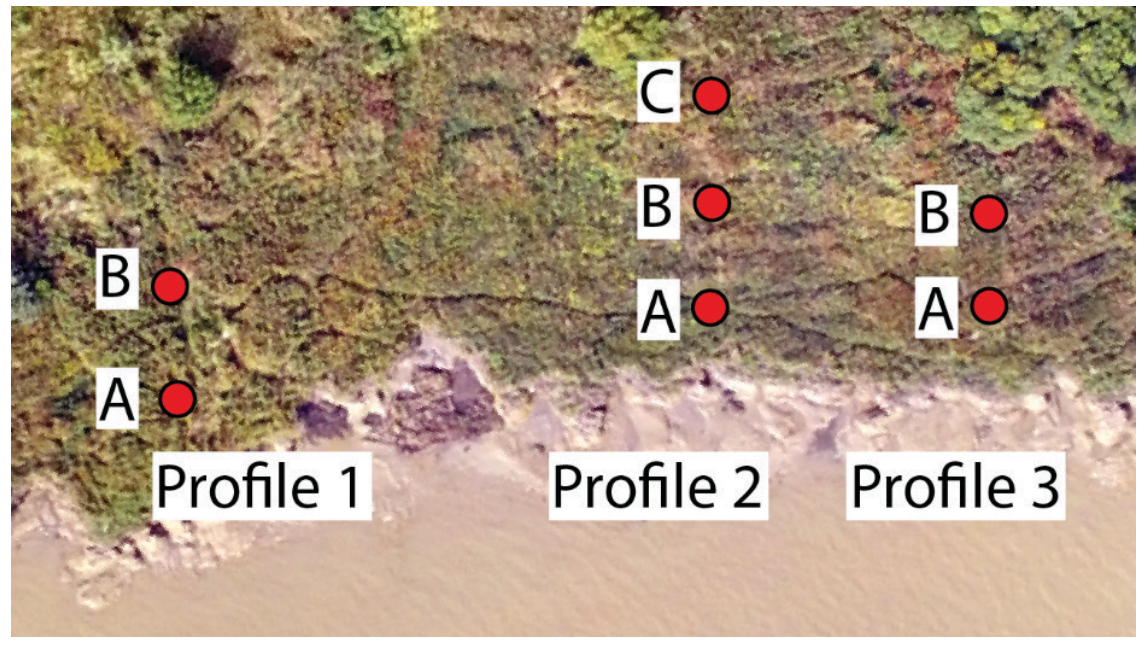

This is a birds-eye view of a stake site in Dillingham. Three profiles run perpendicular to the shoreline, and the stakes are labeled alphabetically from the shoreline inland. We placed a third stake on profile 2 because stake A could be lost to erosion from one storm. 
4. Use a handheld GPS or smartphone to get the coordinates of each stake (if possible, using WGS84). Let the device sit for at least 5 minutes in order to get the most accurate position before collecting the latitude and longitude (see red box in figure below). If your GPS has a value for accuracy, write it in your field notes.
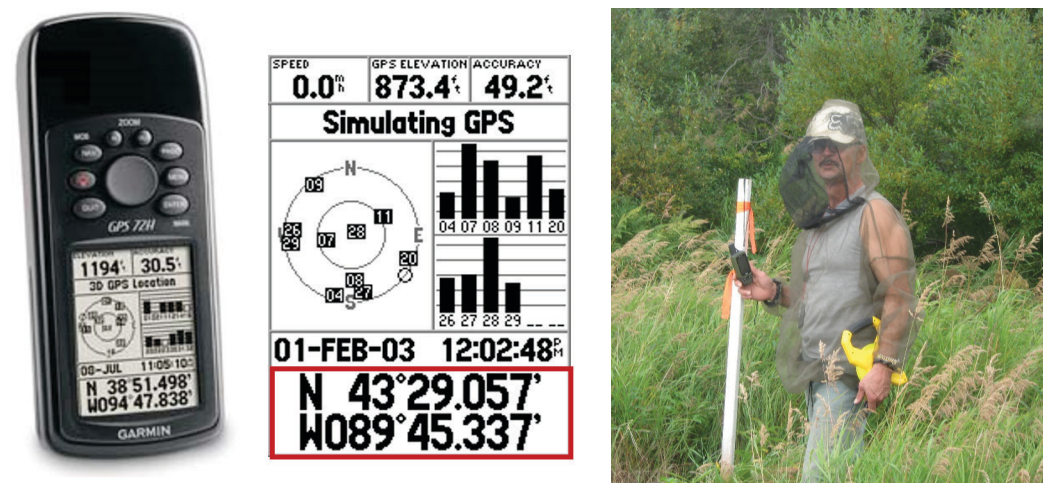

5. Use a tape measure to get the distance between stakes $A$ and $B$ along the profile (include additional stakes if you've installed more than two). If there are any buildings nearby, you can also measure the distance to those buildings to help retrace your profile later, in case stakes are lost.

6. Measure the bearing of the profile using a compass. Stand far back from the stakes and move to where you are on the profile (the stakes line up from your perspective). Compasses are affected by metal, make sure there aren't rings or large metal stakes nearby! Record the bearing, and note whether it was adjusted for declination.

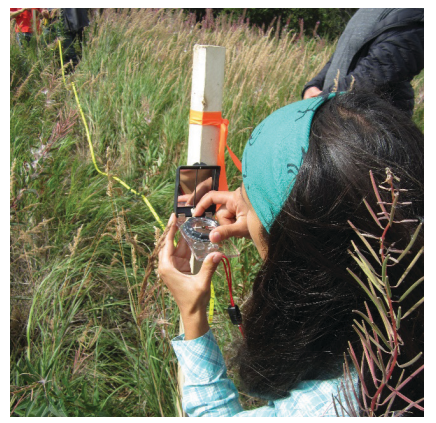

7. Optional: Adding a camera or taking photos. If you take pictures of the site over enough time, you can actually measure the erosion from the photos! See instructions for this method in the next section. 


\section{Measuring Erosion Using the Stake Site:}

1. Attach (or have one person hold) the tape measure to the seaward stake.

2. Measure out to the bluff or erosion feature. Double-check that you are still along the imaginary profile line drawn by the two stakes. By staying on the profile, you will take a consistent measurement. Keep the tape measure taut and level. The person in blue is checking that he is along the profile, and keeping the measuring tape taut.

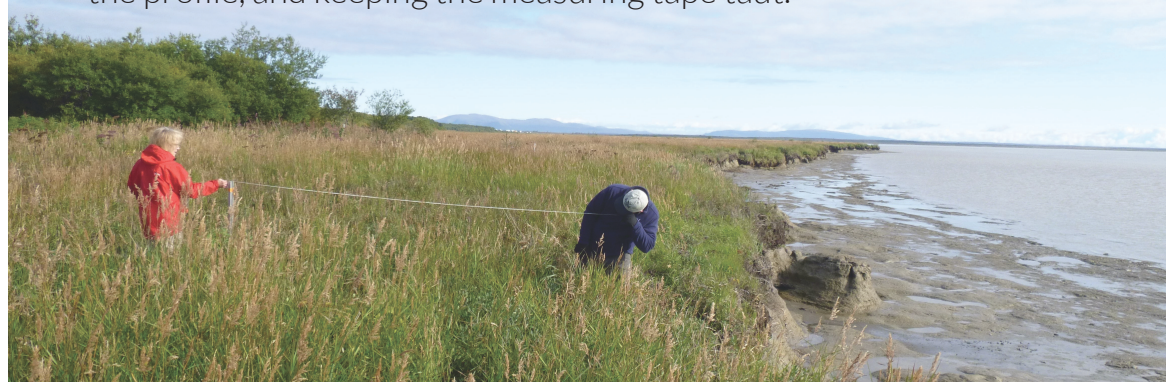

3. Make note of any changes to the site, such as lost stakes, new debris from storms, or landscape changes. Other things to note are big storms and tides, sea ice conditions, and warm winter temperatures.

4. Keep a measurement log for your site. The log should include the profile number, date, distance measured, and notes. See the data sheet on the next page.

\section{Monitoring Tips:}

Safety: Visit sites with a partner and be vigilant of wildlife, weather conditions, and dangerous changes to the site such as new gaps forming in collapsing bluffs. Use caution on tall bluff edges; get creative about making measurements so as not to get too close to the edge. You can attach a heavy item to the end of your measuring tape, toss that end over the bluff, and slowly reel it in until it reaches the bluff edge.

Site longevity: You can place several stakes along a profile to preserve the profile in case some stakes are lost. You could also place a marker in the ground (e.g. a survey nail with a flag) at the stake locations.

More site coverage: You can place multiple profiles along the shoreline to map greater areas. 
Location: Old Meshik Town Site

Date: $2|28| 18$

Data Collection Team:

\begin{tabular}{|c|c|c|c|c|c|}
\hline Transect \# & Stake Label & $\begin{array}{l}\text { Compass } \\
\text { Bearing }\end{array}$ & $\begin{array}{l}\text { Distance } \\
\text { from Stake } \\
\text { to Edge }\end{array}$ & $\begin{array}{c}\text { Units } \\
\text { (feet or } \\
\text { meters) }\end{array}$ & Notes \\
\hline 1 & PTHGL0101 & 82 & $40^{\prime}$ & Feet & \\
\hline 1 & PTHGL0102 & 82 & & Feet & 2 stake eroded \\
\hline 2 & PTHGL0201 & 87 & $31^{\prime} 5$ & Feet & \\
\hline 2 & PTHGL0202 & 87 & & Feet & :almost $19^{\prime} / 2$ st loss \\
\hline 3 & PTHGL0301 & 120 & $120^{\prime} 4^{\prime \prime}$ & Feet & \\
\hline 3 & PTHGL0302 & 120 & & Feet & $23 \mathrm{ft} . \operatorname{loss}$ \\
\hline 4 & PTHGL0401 & 119 & $191^{\prime} 5^{\prime \prime}$ & Feet & \\
\hline 4 & PTHGL0402 & 119 & $64^{\prime}$ & Feet & Apponx. $16^{\prime} / 2 f+10 s 5$ \\
\hline 5 & PTHGL0501 & 128 & & Feet & \\
\hline 5 & PTHGL0502 & 128 & & Feet & $160 \mathrm{ft} .105 \mathrm{~s}$ \\
\hline 6 & PTHGL0601 & 102 & $\left(0^{-1}\right)^{\prime \prime}$ & Feet & \\
\hline 6 & PTHGL0602 & 102 & & Feet & $2^{\text {nd }}$ stake eroded \\
\hline 7 & PTHGL0701 & 106 & $83^{\prime} 6^{\prime \prime}$ & Feet & \\
\hline 7 & PTHGL0702 & 106 & $17^{\prime} 10^{\prime \prime}$ & Feet & $14 \mathrm{ft} .10=\mathrm{s}$ \\
\hline
\end{tabular}

Comments:

Don't forget to take photographs!

Coastal Geoscience Program

Alaska Division of Geological and Geophysical Surveys
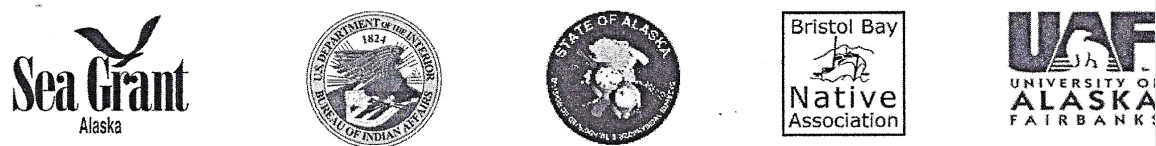

ALASKA FAIRBANK 


\section{How Often Should I Measure?}

Measure once every 1-3 months, as well as immediately before and after storms. Increase the frequency of collection during periods with a lot of change.

By measuring consistently, you can determine when and how fast erosion is during certain events or times of year. This rate of erosion (how fast the shoreline is moving) helps future planning. Later, if erosion rates increase or an anomalous event occurs, you have data to show this is the case.

The following figure shows erosion at one profile in Port Heiden. Community members used the stake method to show when erosion is occurring and how much erosion is caused by fall storms.

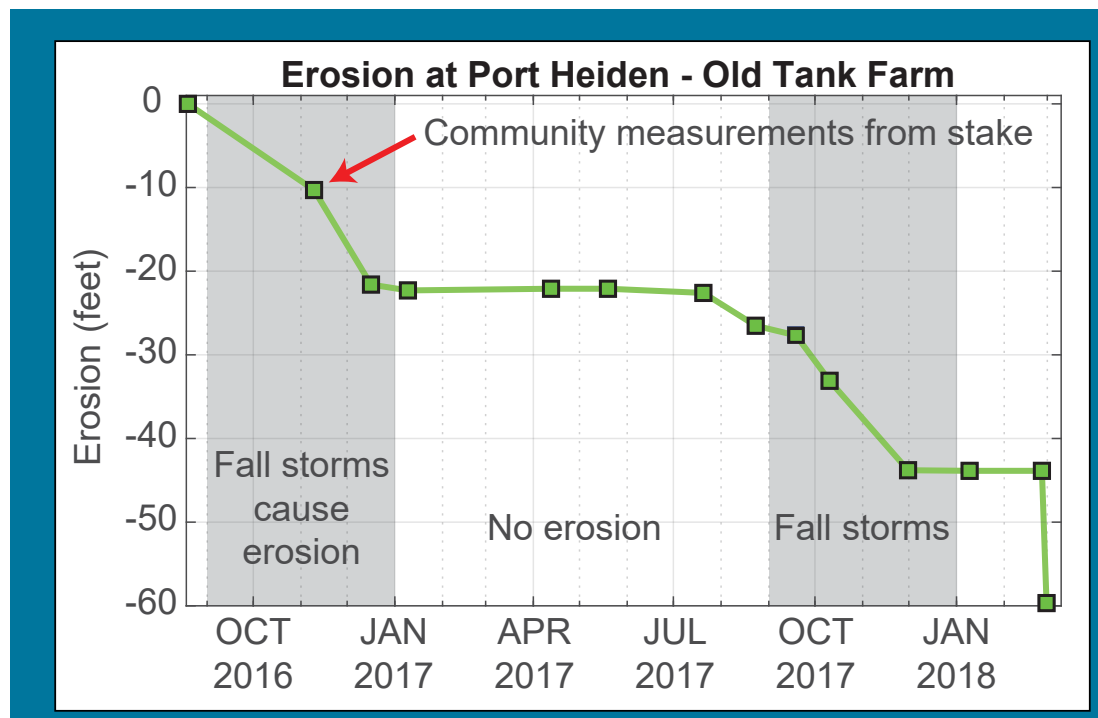

This graph shows erosion (y-axis) over time (x-axis). Each green square is a community measurement. The community measured over 20 feet of erosion in fall of 2016, and another 20 feet in fall of 2017. They also measured directly before and after a storm in 2018, finding that it eroded the bluff by 17 feet. 


\section{SHORELINE EROSION: STAKE AND CAMERA SITE}

\section{Required Materials:}

- An established stake monitoring site (see last section)

- Time-lapse camera

-SD card

- Mailing materials

- Materials to mount the camera
When taken in a certain orientation, photographs can also be used to track where the shoreline is through time. The results from a time-lapse camera are similar to using a measuring tape, only there are many more measurements being taken (by the camera), and there are photos of exactly what is causing the change.

Decide if your site needs a camera: if a site is difficult to access, or has rapid erosion, it is worth installing a camera. The results look like this:

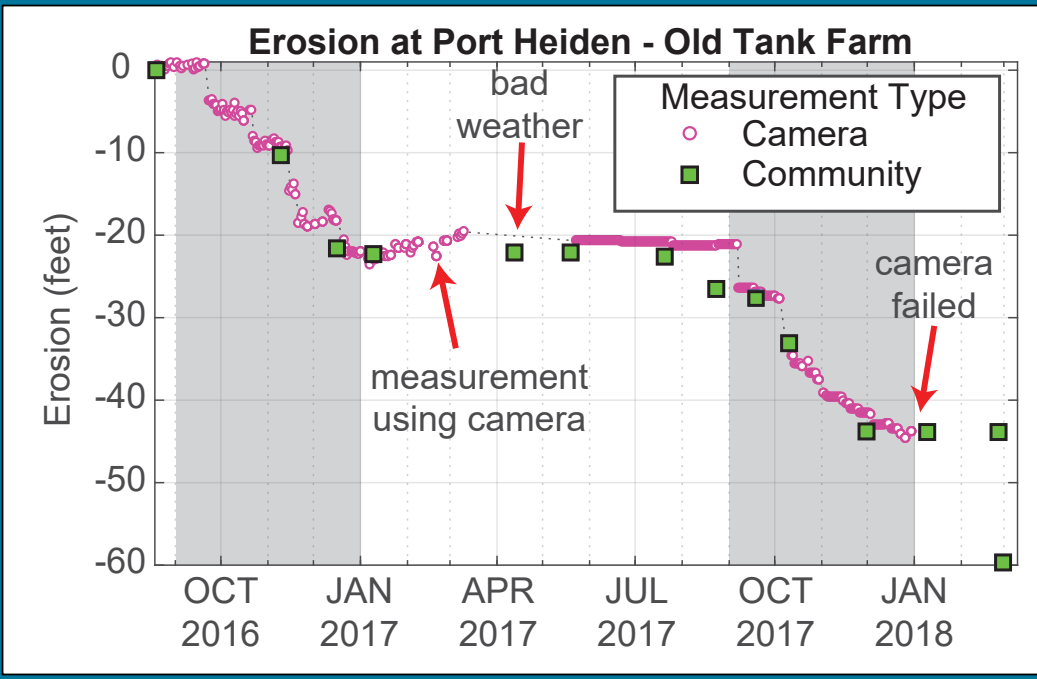

This graph shows the same erosion data as the previous graph, but we also made measurements using a time-lapse camera (pink circles). There were many more camera measurements than tape measurements (green), so we saw a clearer picture of how the bluff eroded over time. However, the camera failed at certain times, so we would not have detected erosion without the help of the community. 
Benefits: The camera captures specific erosion events, distinguishing them from more gradual erosion. It also sees the cause (e.g., flooding, waves, ice conditions). If a site is difficult to access often, the camera is especially useful for taking regular measurements.

Limitations: Camera measurements can be noisy (points jumping up and down). Bad weather prevents measurements, and cameras can fail for various reasons. The cameras are a great tool, but tape measurements are still needed to ensure accuracy and fill gaps.

Recommendations: One camera is recommended for identifying erosion rates and causes at a location. Frequent ground-based measurements are needed to validate camera measurements. In addition, cameras can run out of battery power or malfunction without warning, so the only way to ensure reliable and consistent measurements is to also measure erosion often with a measuring tape.

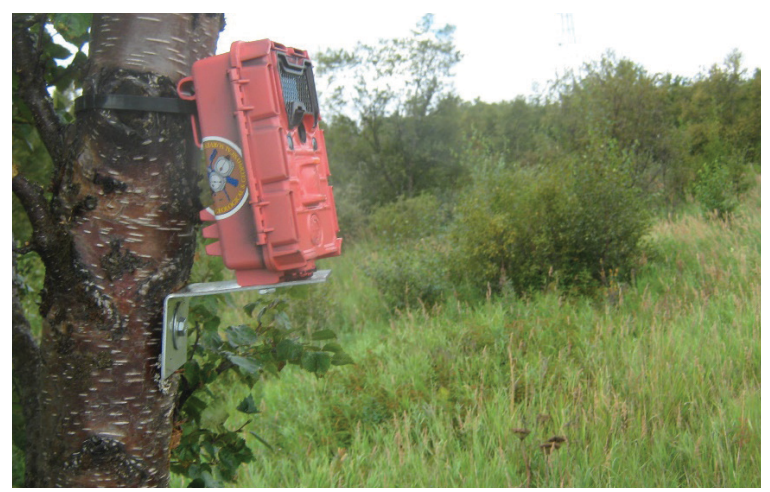

This Bushnell HD Aggressor camera was mounted to a tree using common hardware and a zip tie. We painted over the motion sensor to disable it, so the camera only takes time-lapse pictures.

\section{Installation:}

1. Install two profiles according to the instructions in Section 1.

2. Pick a location nearby, but far enough to see the stakes of both profiles and the eroding feature in one image.

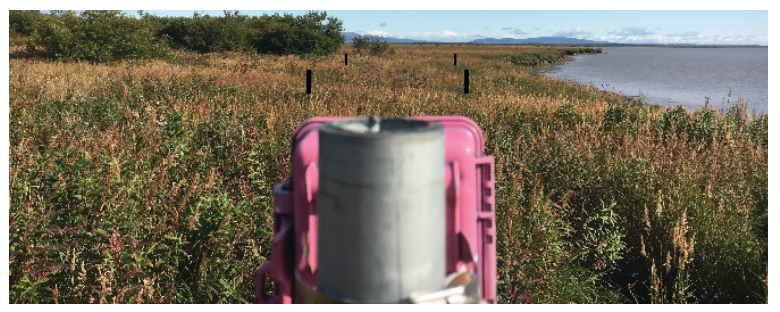

This camera can see the stakes of two profiles, and the bluff edge. It is facing perpendicular to the profiles. 
3. Position the camera to take pictures straight ahead (not tilted up or down) and directly perpendicular to staked transect.

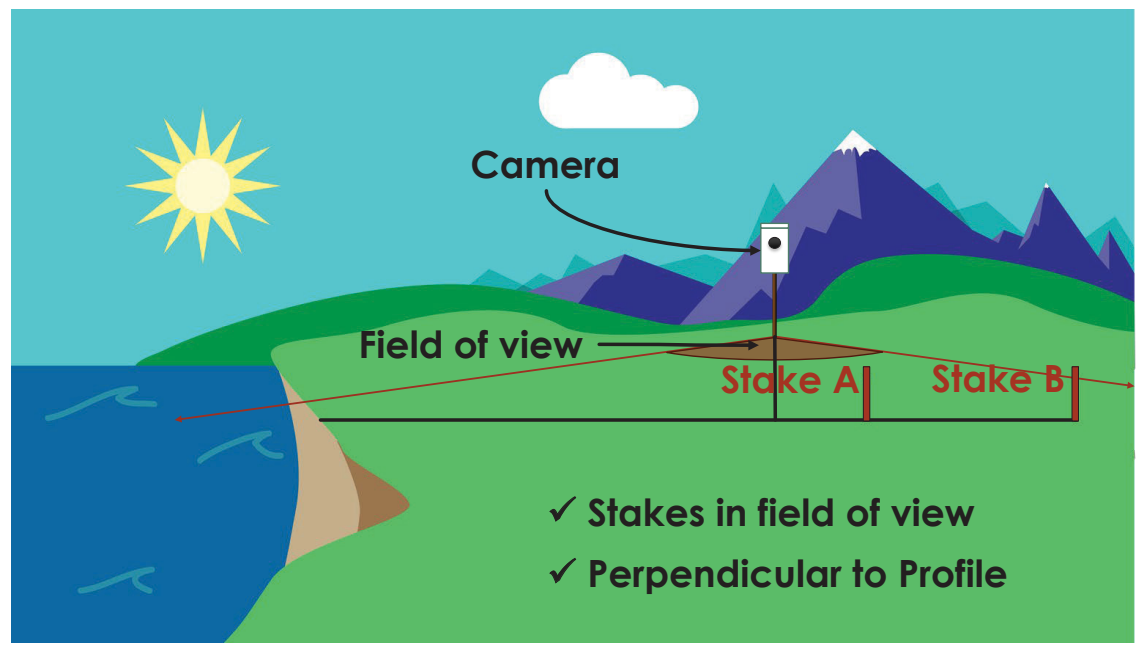

This mock-up shows a similar scenario as the image above. By keeping the camera facing perpendicular to the profile, distances can be measured on the profiles.

4. Format your camera settings so it takes images at a reasonable time interval. See Monitoring Tips after these instructions.

5. For each profile, use the tape measure to take the distance between each stake, and also measure the distance from stake A to the shoreline feature you are monitoring (vegetation line, bluff edge, etc.). This information is required to calibrate the camera for future measurements. 


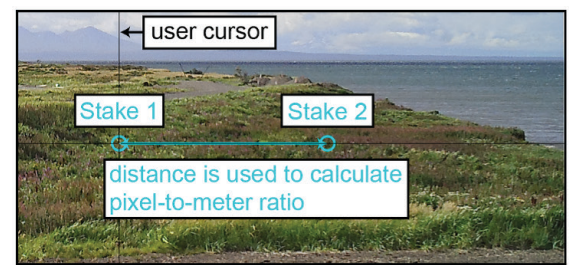

1. Identify stakes, input ground-measured distance

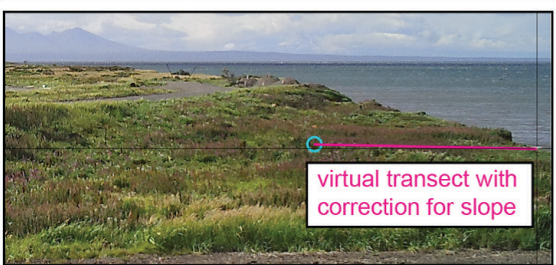

3. Function draws virtual transect to reference

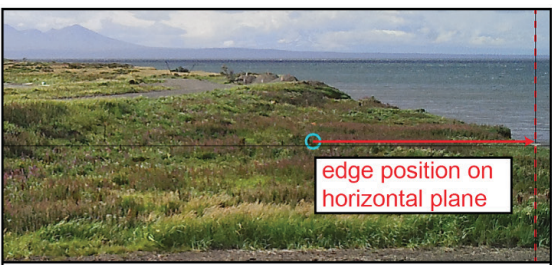

2. Identify edge based on known initial distance

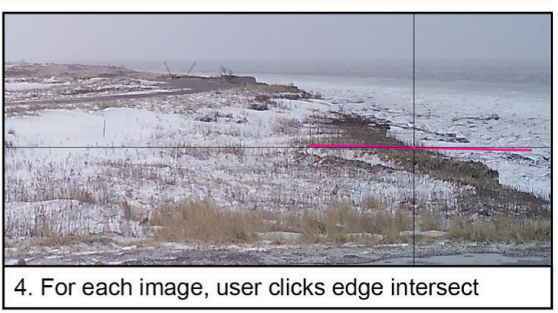

This four-panel figure shows how we make measurements from time-lapse images. We use the initial ground-measured distance between the stakes (1) and the bluff edge (2) to determine where the profile is and how long it is (3). Then we can measure how much it erodes over time (4).

\section{Collecting Camera Images:}

Turn the camera off and remove the SD card. Keep a second SD card on hand so you can immediately install it in the camera and turn it back on. This way you will not miss any data while processing/mailing the first SD card.

Take stake measurements. This helps us validate the changes measured by the camera, and is a back-up in case the camera malfunctioned.

Check that your camera is okay to function until the next collection. Things to look at include:

- Battery level

- Lens obscurations (dirt, snow, bugs)

- Camera settings

- Image quality

- Camera orientation 


\section{Sending Images to DGGS:}

- Back up your images on a local computer. This is your community site and you worked hard for these images!

- Contact us either by phone or email to let us know you will be sending the images. Then we can assure you when we receive them, and also notify you if we have an address change.

- Package the images. You could send the images through an online file-sharing format, but given the large file size it is often easier to just mail the SD card. Put your SD card (or a USB device with the images) in a padded envelope (padding protects the card from damage). Include details about your site so we know where the data is coming from and what your camera is monitoring (e.g., Dillingham: Sewage Lagoon Camera).

- Mail your envelope to the address below. When we receive it, we will download the images to our file server and mail your device back to you. Remember to back up your images before putting them in the mail.

\section{Mailing Address:}

Attn: Jacquelyn Overbeck Alaska DGGS

3651 Penland Pkwy Anchorage, AK 99508 Email: jacquelyn.overbeck@alaska.gov

Phone: 907-451-5026 


\section{Monitoring Tips:}

How often should you send photos? It is good practice to send photos every three months. This requires only four site visits a year, which is enough for regular site and camera upkeep. If a significant storm or event occurs and there is substantial shoreline change, you may consider sending in your photos right away.

Will the camera survive the winter? We have found that the Bushnell HD Aggressor cameras, which use eight AA batteries, have lasted one year without battery replacement on the southwest coast of Alaska.

Temperatures in winter generally stayed below freezing and sometimes dropped below $\mathrm{O}^{\circ} \mathrm{F}$, and the camera still functioned normally.

How much data is this? We use 1-hour intervals with a setting that turns the camera off at night. Depending on frequency of erosion, you may want fewer or more images. At 1-hour intervals, 24 hours a day, with an average image size of $2 \mathrm{MB}$, the camera would collect almost $13 \mathrm{~GB}$ of images in one year. Cheap SD cards today easily hold 16 GB.

Keep camera measurements consistent: When you collect the images, try to keep the camera at the exact same position as when installed. Drawing lines on the camera and the mounting setup help to realign the camera each time it is moved (see below).

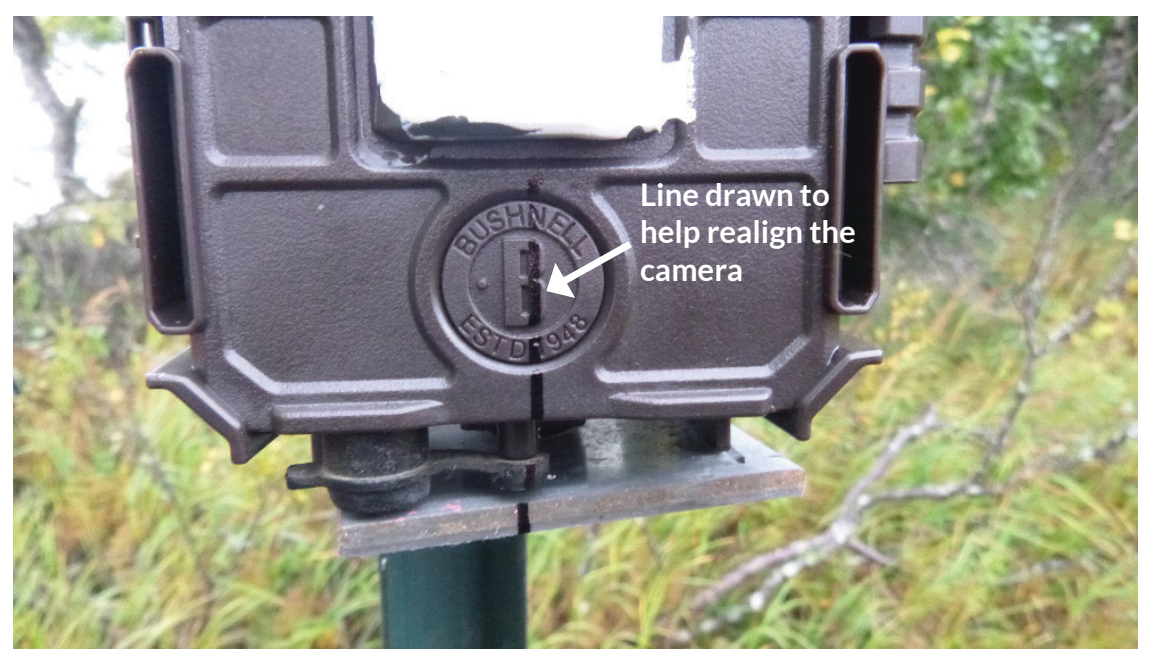




\section{BEACH EROSION: CROSS-SHORE PROFILE SITE}

\section{Required Materials:}

- An established stake monitoring site

- A visible horizon or hand level

- "Emery rod" apparatus (two straight pieces of wood with measured intervals and a connecting rope)

- Data sheet

- Camera
Cross-shore profiles show the elevation of the beach. They can be used to measure changes in beach volume and shape. If your beach is eroding, accreting, widening, or shortening, consider using cross-shore profiles to document these changes.

Some beaches change often, and others only change significantly after large weather events or when people add beach infrastructure, such as docks or sea walls. Even if your beach seems stable now, it may undergo significant change

in the coming years. Documenting beach elevation before change occurs is very important. The data can later be used to determine the amount of change, and possibly attribute causes for the change.

This method requires at least 3 people and can be time-intensive, but provides much more information about the dynamics of the coastal environment at your community.

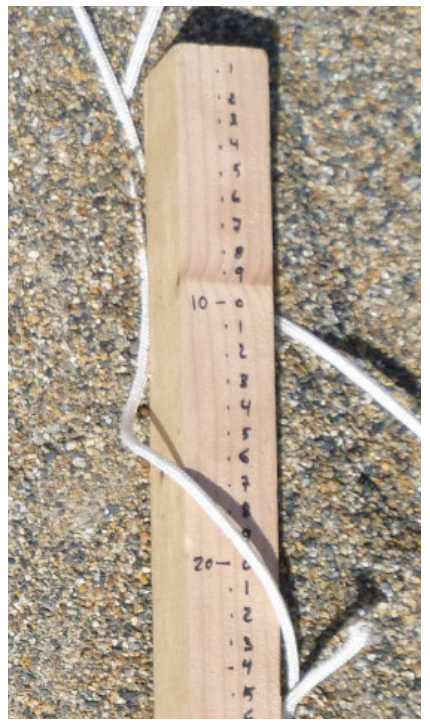

\section{Making Emery Rods:}

You will need:

- Two straight pieces of wood, 2 meters long

- One string just longer than 5 meters

- One black marker

- One meter stick

Use the meter stick to mark off every centimeter of the rod, making larger marks every 10 centimeters. Number the large marks $(0,10,20, \ldots)$, starting with zero at the top and 200 at the bottom $(200 \mathrm{~cm}=$ $2 \mathrm{~m}$ ). Wooden rods can be painted to increase the contrast between the marks.

These overachievers marked their rods at every centimeter. 


\section{Using the Data Sheet:}

The data sheet is designed to help you write down all the information you need without doing math in the field. See the filled-out datasheet at the end of this section for an example. Here is the basic format to keep in mind as you read through the instructions.

\begin{tabular}{|l|l|l|l|}
\hline $\begin{array}{l}\text { Segment } \\
\#\end{array}$ & Spacing & Change in elevation & Notes \\
\hline & $\square$ fixed or & $\square$ up $\square$ down & \\
\hline$\square$ fixed or & $\square$ up $\square$ down & \\
\hline$\square$ fixed or & $\square$ up $\square$ down & \\
\hline
\end{tabular}

Segment \#: Use one row for each measurement. Number the rows, starting with 1, to keep track of how many you have done.

Spacing: If you use the full string length, check fixed. Otherwise write the length you used. You could use the rods to get this measurement.

Change in elevation: Write the heights each rod-holder calls out. If their numbers are 80 and 120, write "80 - 120." Try to keep the order consistent, such as landward to seaward. Then check the box for up or down to say whether the profilers moved uphill or downhill.

Notes: Write things down about the profile, such as "pebbly" or "sandy" beach, "in tall grass," or "at bluff edge." This helps visualize the profile, and determine how things changed.

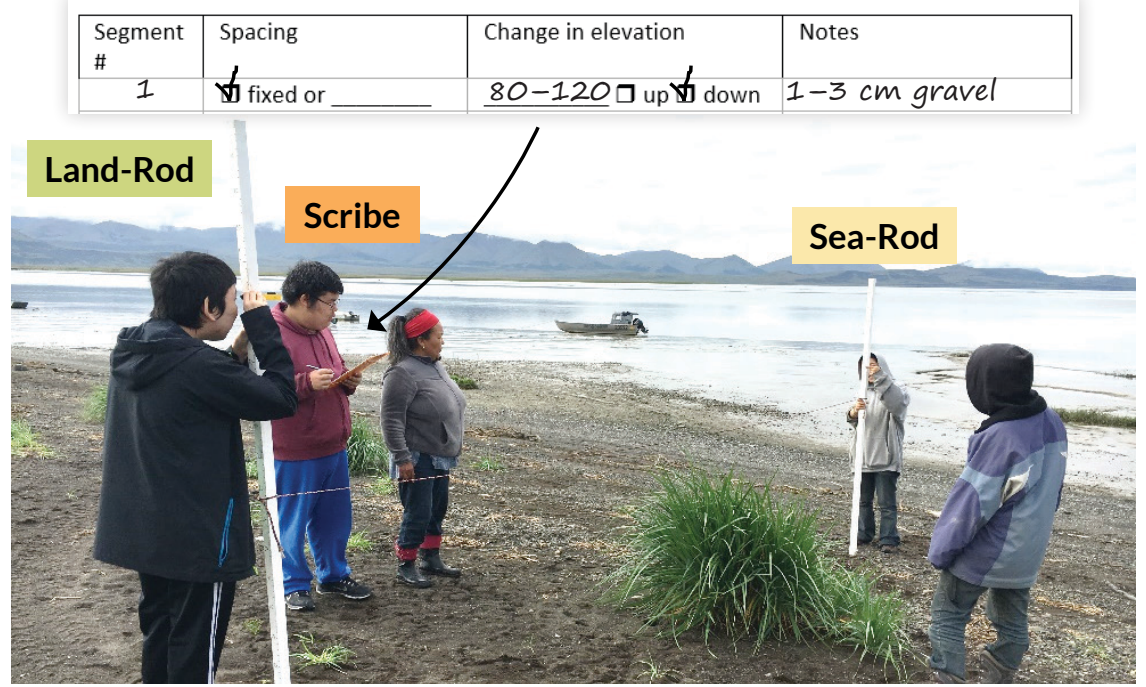




\section{Installation:}

Install a stake site profile according to the instructions in Section 1. This will be your reference marker where you will start the Emery rod collection every time. For your first time, we recommend that you measure the same profile twice to practice and see how consistent you can be.

\section{Collecting Data:}

The main idea is that two people, one per rod, leap-frog down the beach with the Emery rods. We call these two people Land-Rod and Sea-Rod, based on who is closer to the water. The third person is the Scribe; they write down the difference in height between the two rods.

\section{Detailed instructions are available on a YouTube video created by Maine Sea Grant at: https://www.youtube.com/watch?v=NaF7Pq2HkxA}

1. Get your bearings: Fill out the top of your data sheet (date, weather, visibility, location, team member names, profile number, compass bearing).

2. Plan your profile: You want to start at the same spot and walk in the same direction every time you measure this profile. Try starting at your landward stake.

3. Begin! Land-Rod holds their rod at the starting stake and stays still.

4. Walk the walk: Sea-Rod walks towards the water, along the profile, until the rope is taut or until they reach a feature of interest (e.g., a stake, bluff edge, or water's edge).

5. Line up: Sea-Rod needs to move the foot of the rod until it is on the profile. Let the Scribe help you line up! 


\section{Tip 1}

If stakes are in view, Sea-Rod can visually line themselves up using the stakes and Land-Rod. In the picture at right, we used telephone poles as stakes. Be creative!
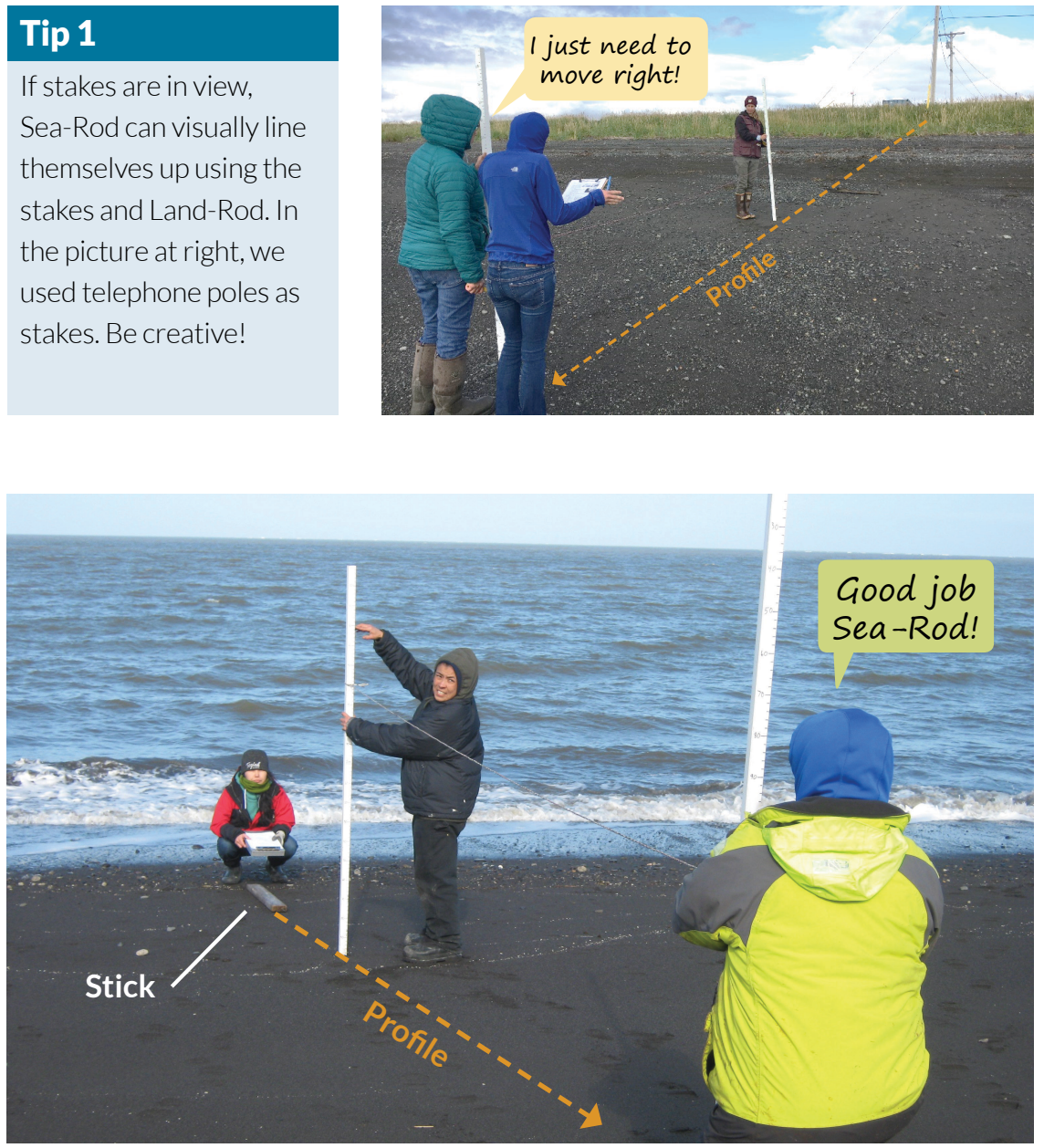

\section{Tip 2}

Another option is to place a stick down the beach on the profile. Then the rod holders simply leap-frog towards the stick. Place the stick before you begin, using either the two stakes or the compass bearing to stay on the profile. Then the Scribe or Land-Rod can help Sea-Rod stay on the profile using the imaginary line drawn from Land-Rod to the stick. 
6. Measure: First, Land-Rod must pick a number on their rod, and place their eye at this number. Land-Rod looks at where the horizon intersects the other rod, then Land-Rod must instruct Sea-Rod to move their hand up or down to this intersection point.

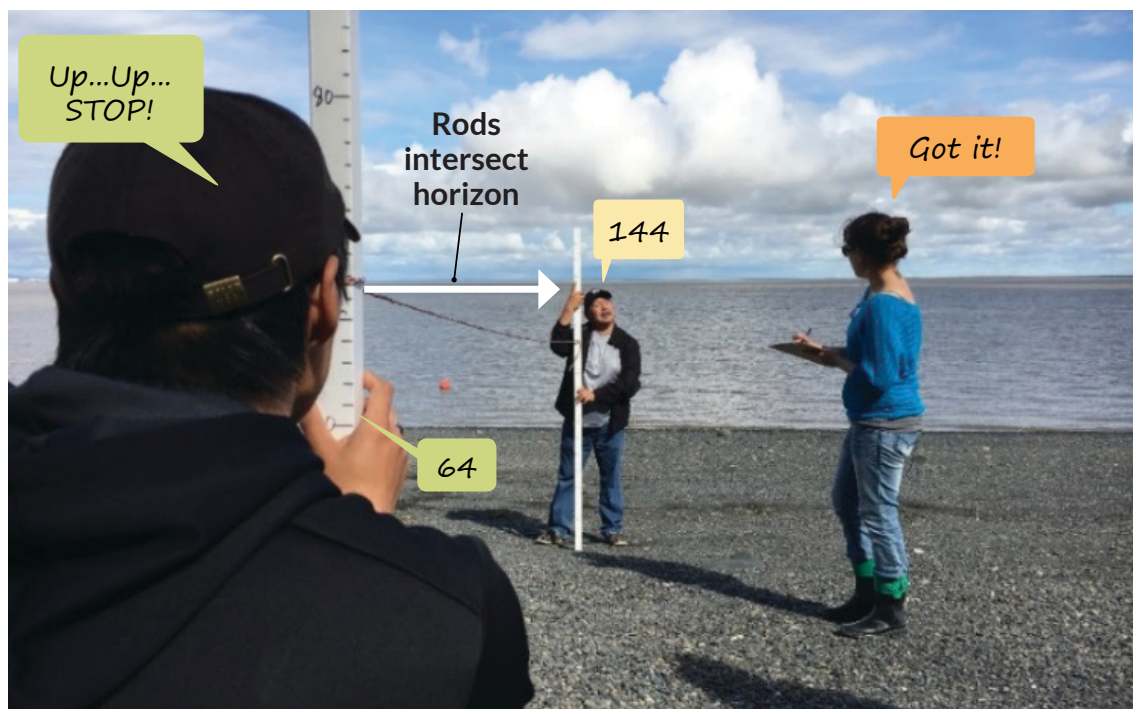

7. Record it: Land-Rod and Sea-Rod yell out their numbers to the Scribe, who writes them down landward-to-seaward. Then they check a box to say whether they moved up or down in elevation.

\section{Tip 3}

Rather than doing math in the field, it is easier to just record the rod heights. Later you can calculate the difference. In the example above, the rods went downhill by $80 \mathrm{~cm}(144 \mathrm{~cm}-64 \mathrm{~cm})$. We know they went down because the Scribe checked the down box.

\section{Tip 4}

Instead of the horizon, you can use a sight level (a bubble level within a telescope).

8. Leap-frog! Sea-Rod stays put, and Land-Rod walks to Sea-Rod. Carefully swap the rod positions without digging into the ground. Now Land-Rod stays put where Sea-Rod used to be, and Sea-Rod can walk the walk. Repeat steps 4 through 8. 
9. Photograph: After you reach the water, take a few photos of the area you measured. It is nice to have people in the picture so you can tell how big things are. Make sure at least one photo captures the whole profile, like the one below.

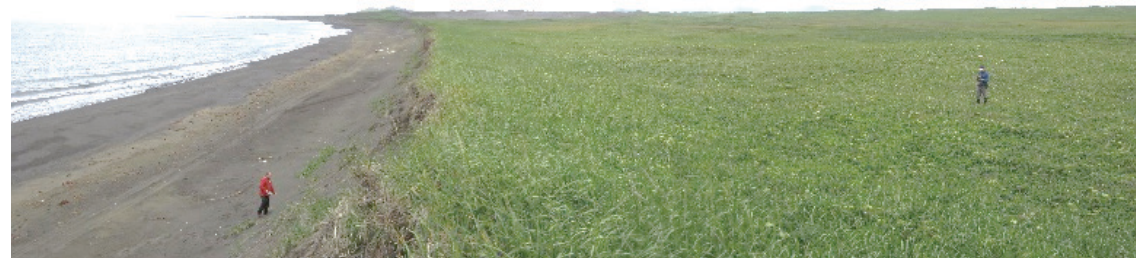

\section{Monitoring Tips:}

- Always assess your safety while choosing a location to measure with Emery rods. Bluffs taller than 2 meters are not safe.

- To keep your profiles consistent, always start at the same point. If the start point could change in elevation (such as sand at a sea wall), record the height between the sand and some permanent part of the starting object (e.g., a bolt in the sea wall).

- When necessary, you can change the space

between your rods. The profilers in the picture below kept the rods closer together to measure the bluff height. After getting the height, they measured the distance between rods using the string.

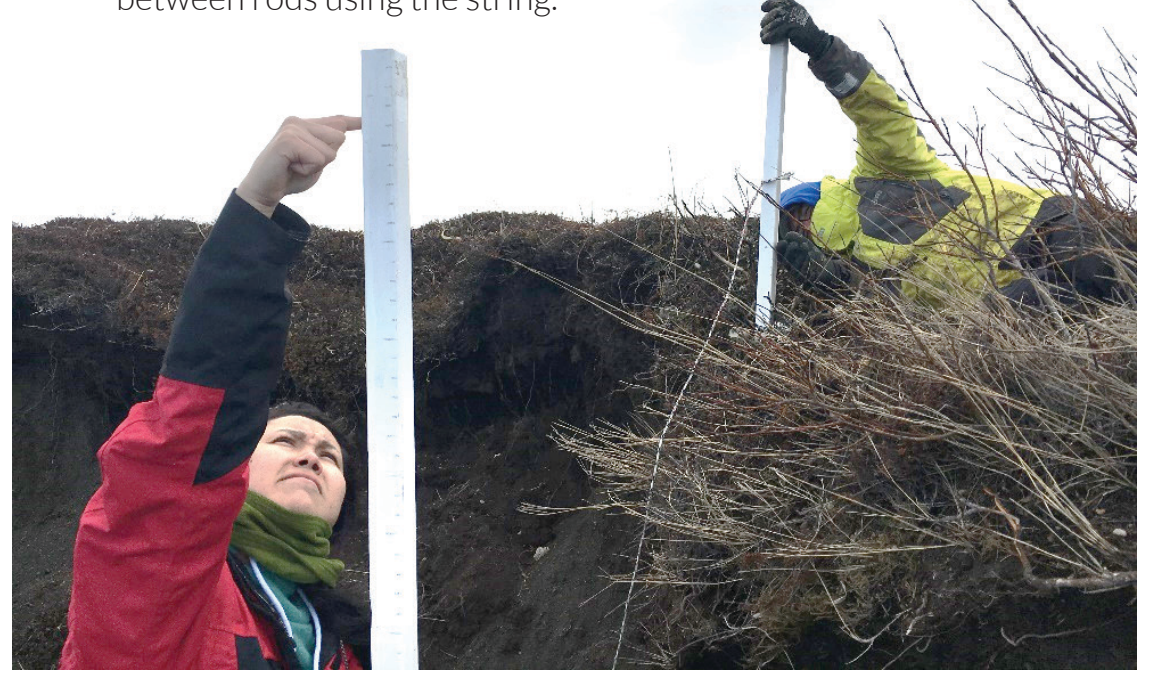




\section{Sending the Data:}

You can mail or e-mail a scan of the data sheet to us. If you send us a flash drive with the photos, we will return it to you promptly.

Here is an example of a good data sheet.

\section{Coastal Elevation Profile - 'Emery Rod' Data Sheet}

Coastal Geoscience Program

Division of Geological \& Geophysical Surveys

3354 College Road

Fairbanks, AK 99709

http://www.dggs.alaska.gov/
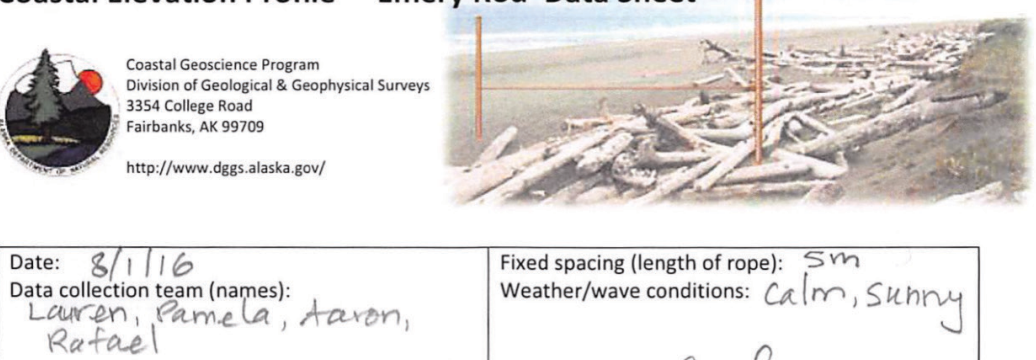

Fixed spacing (length of rope): $5 \mathrm{~m}$

Weather/wave conditions: $\mathrm{Calm}$, Suhny Horizon visibility: Good

Location: BehSON Transect ID: CBM 2 compass bearing: 170

Latitude of First Point:

Longitude of First Point:

Time at start: $14: 45$

\begin{tabular}{|c|c|c|c|}
\hline Segment \# & Spacing & Change in elevation & Sediment grain size or other notes \\
\hline & D fixed or & $92-5 \square$ up 2 down & \\
\hline 2 & 娄ixed or & $51-35 \square$ up $又$ down & \\
\hline 3 & Q fixed or & $6-25$ ㅁ up $\Omega$ down & across \\
\hline 4 & $\square$ fixed or $2 \mathrm{~m}$ & $7-118 \otimes$ up $\square$ down & \\
\hline 5 & $\square$ fixed or $\frac{1 m}{1 m}$ & $10-36$ 的 $\square$ down & \\
\hline 6 & $\square$ fixed or $\underline{0,5 \mathrm{~m}}$ & $35-34$ up 9 down & (a) bluffedge \\
\hline 7 & $\square$ fixed or $\overline{0.5 \mathrm{~m}}$ & $145-26$ up d down & beach \\
\hline 8 & $\square$ fixed or $2.0 \mathrm{~m}$ & $80-11 \square \square$ up $\triangle$ down & beach \\
\hline 9 & $\Delta$ fixed or & $131-10$ u 8 down & beach \\
\hline 10 & 囚 fixed or & $95-11-\square$ up $囚$ down & beach \\
\hline 11 & $\Delta$ fixed or & $19-11$ a u 8 down & beacl \\
\hline 12 & 8 fixed or & $15-10 \square$ up down & \\
\hline 13 & $\square$ fixed or & $19-11-9$ up 8 down & \\
\hline 14 & Q fixed or & $8-10 \square$ up $\pi$ down & \\
\hline 5 & fixed or & $70-101 \square$ up 8 down & \\
\hline 16 & $\nabla$ fixed or & $73-10 \square$ up 0 down & zone \\
\hline & $\square$ fixed or & $\square$ up $\square$ down & \\
\hline & $\square$ fixed or & $\square$ up $\square$ down & \\
\hline & $\square$ fixed or & $\square$ up $\square$ down & \\
\hline & $\square$ fixed or & $\square$ up $\square$ down & \\
\hline & $\square$ fixed or & $\square$ up $\square$ down & \\
\hline & $\square$ fixed or & $\square$ up $\square$ down & \\
\hline
\end{tabular}

Time at completion: $15: 22$

Comments or notable features/changes: 


\section{Draw Your Profile:}

When you return from the beach, you can calculate the change in elevation.

1. Take the difference of the two heights (for segment 1 in the last example, this is $92-5=87$ ).

2. Make the number negative if the "down" box is checked, and positive for "up". Now we have -87.

3. So the profile went the horizontal distance of the segment (in meters), and the vertical distance of the height (in centimeters). For segment 1 , the profile went 5 meters toward the water, and $87 \mathrm{~cm}$ downhill.

4. Draw this line on graph paper. Calculate the next line and have it begin where your last line ended.

After doing these steps for each segment, you will have drawn the beach profile you just walked. If you collect another profile here later, you can draw it from the same starting point and see how much it has changed!
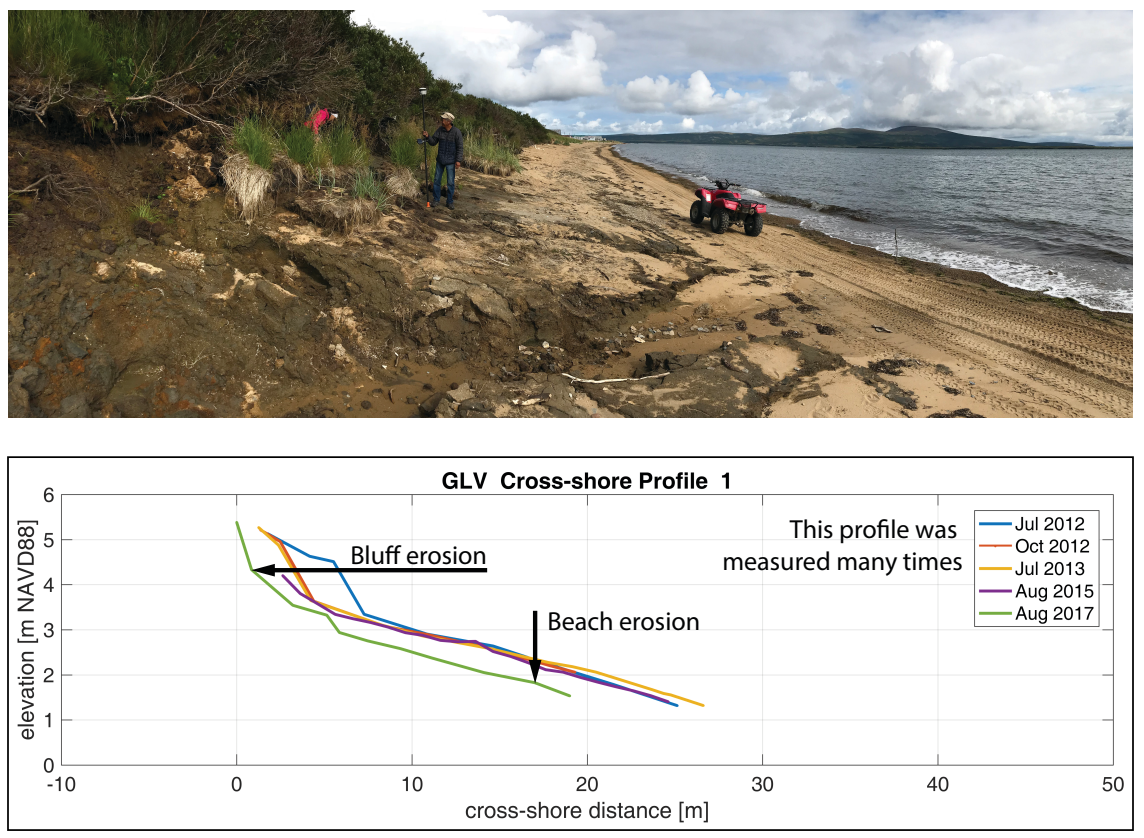

This beach at Golovin has been measured five times over five years. The x-axis is the horizontal distance from the bluff to the water. The $y$-axis is the height of the ground along this profile. The repeated profile measurements tell us how the beach is changing; the blufferoded about 5 meters over the time period, but the beach was stable for three years and then eroded about $50 \mathrm{~cm}$ in two years. 


\section{EQUIPMENT MAINTENANCE/INVENTORY}

Any time you replace equipment or something is moved/lost, record it in the following maintenance logs.

\section{Camera}

\begin{tabular}{|l|l|l|l|l|l|l|}
\hline $\begin{array}{l}\text { SD card replacement } \\
\text { and retrieval date: }\end{array}$ & & & & & & \\
\hline $\begin{array}{l}\text { Battery replacement } \\
\text { date: }\end{array}$ & & & & & & \\
\hline
\end{tabular}

Camera replacement, relocation, recalibration, other:

Include GPS position, lens bearing, explanation of conditions, any other related information.

\section{Stakes and Transects}

\begin{tabular}{|l|l|l|}
\hline $\begin{array}{l}\text { Transect } \\
\text { ID }\end{array}$ & $\begin{array}{l}\text { Stake } \\
\text { Code }\end{array}$ & $\begin{array}{l}\text { Notes: Date, action taken (relocation, newstake, etc.), other applicable } \\
\text { information (coordinates of new stake, bearing, etc.). Remember to fill } \\
\text { out Stake Measurement Data Sheet for new or relocated stakes! }\end{array}$ \\
\hline & & \\
\hline & & \\
\hline & & \\
\hline & & \\
\hline & & \\
\hline
\end{tabular}




\section{POTENTIAL FOR ERRORS}

As a citizen scientist, your goal is to reduce potential errors to ensure your data is accurate. Even the smallest error can compound into a large one over time if it goes unaddressed. Keep the following types of errors in mind while installing and monitoring your sites:

\section{Site Error}

GPS positions - Handheld GPS can only be so accurate; make sure you let the GPS sit for enough time to get a good reading.

Profile bearing - Use the same bearing every time, even if the direction of the beach changes.

Camera stability - Avoid changing the camera orientation when you collect images. Keep the camera facing 90 degrees from the profile.

\section{Device Error}

Emery rod string - Double-check your string length before you go out to measure. If it's off by $10 \mathrm{~cm}$, that will add up to 1 meter off after ten segments.

Camera image quality - Clearer photos help you get a more accurate measurement of shoreline change. Keep the camera lens clean.

\section{Human Error}

Notetaking - Make sure you write down the correct numbers in the right places, and it is legible.

Taking measurements - If you feel like something is wrong, measure it again and discuss with your team. Maybe a compass is broken, or a tape measure is in feet instead of meters. 


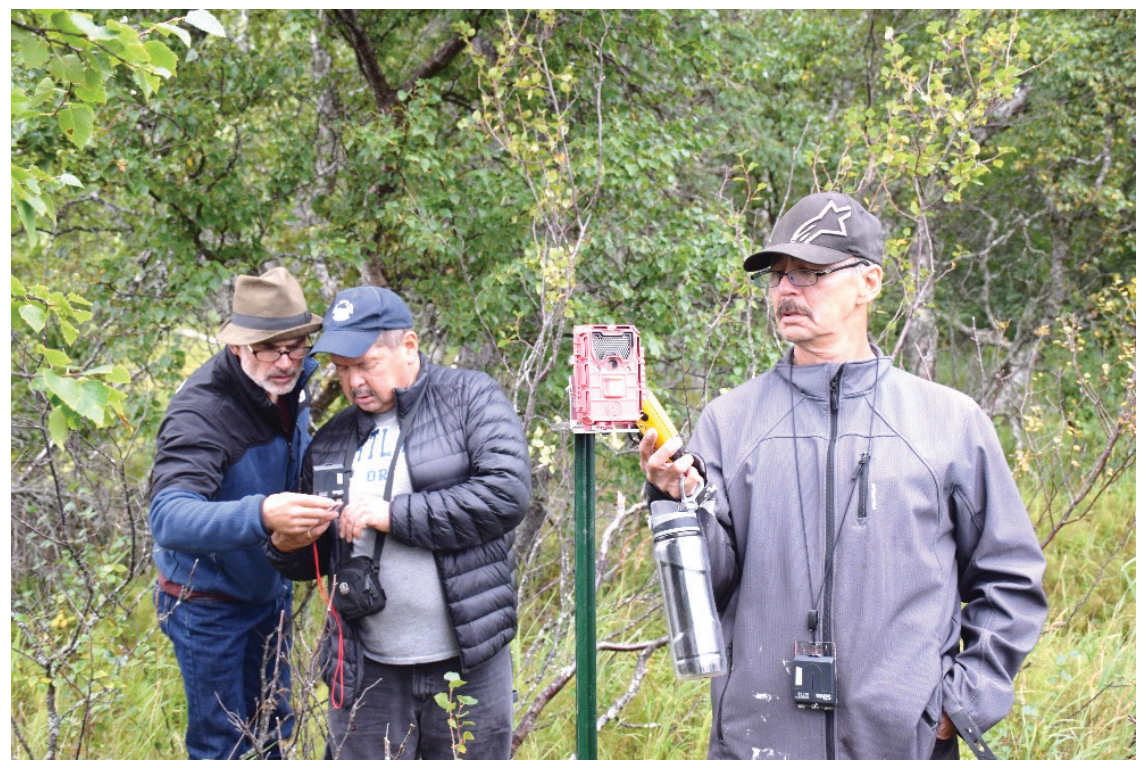

During this site installation, the magnetic compass seemed off. We talked with the team and discovered it was pointing at the metal stake, so we backed up until it pointed north. In the meantime, we hung a GPS on the camera. After it had rested for about ten minutes we recorded its position.

\section{Get Advice}

We can never eliminate error, but it can be minimized by installing the site correctly, using accurate methods, double-checking devices and measurements, and taking good notes.

To be sure your self-installed site will work for this method, contact Jacquelyn Overbeck at DGGS for information on assistance during site installation (see contact information below).

\section{Jacquelyn Overbeck}

Coastal Hazards Program Manager

Alaska Department of Natural Resources, Division of Geological \& Geophysical Surveys

(907) 451-5026

jacquelyn.overbeck@alaska.gov 


\section{USEFUL RESOURCES}

\section{Alaska Coastal Profile Tool (ACPT)}

\section{http://maps.dggs.alaska.gov/acpt/}

This interactive tool enables access to beach elevation profile measurements collected throughout Alaska since the 1960s. The map displays data collected using a variety of techniques.

\section{Alaska Division of Geological \& Geophysical Surveys (DGGS) Coastal Hazards Program}

\section{http://dggs.alaska.gov/sections/engineering/profiles/coastalhazards.html}

DGGS' Coastal Hazards Program investigates how Alaska's coastline evolves and how it will respond to hazardous events and long-term changes. The program website contains aerial photos and elevation models over Alaska communities, links to online shoreline change tools, publications and data products, educational resources, and many other useful tools.

\section{Alaska Ocean Observing System (AOOS)}

\section{http://www.aoos.org/}

AOOS projects focus on increasing access to existing coastal and ocean data, packaging information and data in useful ways, and increasing observing and forecasting capacity in all regions of the state. Visit http://portal.aoos.org/ coastalchange/to view forty years of satellite data on erosion in western Alaska.

\section{Alaska Sea Grant Marine Advisory Program}

https://seagrant.uaf.edu/map/climate/

Sea Grant's website contains climate change adaptation tools, fact sheets, and videos, including resources on changing coastlines. Sea Grant has assisted communities affected by changing shorelines with developing adaptation plans.

\section{Alaska Shoreline Change Tool}

\section{http://maps.dggs.alaska.gov/shoreline/\#-16253081:9110399:3}

This interactive tool displays historic and predicted shoreline position throughout Alaska. Users can explore the coasts of the state to see where shoreline has been in the past, and where it will be in the future. Historic shoreline positions were determined by looking at aerial photographs and satellite imagery dating back to the 1960 s. 


\section{Center for Climate and Health, Alaska Native Tribal Health Consortium (ANTHC)}

\section{http://anthc.org/what-we-do/community-environment-and-health/center-}

for-climate-and-health/

ANTHC's Center for Climate and Health assists communities and helps them to better understand the impacts of climate change and how to adapt in healthy ways. The program provides assessments, technical assistance, training, and monitoring assistance. The program also coordinates with the One Health Group, which provides surveillance on emerging environmental, wildlife, and public health threats. Their website contains climate change reports from all over Alaska as well as climate change maps and newsletters.

\section{Maine Sea Grant Beach Profiling Video}

https://www.youtube.com/watch?V=NaF7Pq2HkxA

Maine Sea Grant has established beach monitoring programs for their coast that use the same methods described here. The video is a great training refresher.

\section{Northern Latitudes}

http://www.northernlatitudes.org/

Northern Latitudes is the leadership of five Landscape Conservation Cooperatives within Alaska and Northern Canada and the Alaska Climate Science Center. Their website includes photos of arctic climate change, including coastal erosion, as well as resources from climate change resilience workshops.

\section{U.S. Climate Resilience Toolkit}

\section{https://toolkit.climate.gov/topics/coastal-flood-risk/coastal-erosion}

The U.S. Climate Resilience Toolkit was developed by a partnership of federal agencies led by the National Oceanic and Atmospheric Administration, and was designed to help people face climate problems and find climate opportunities using plain language. This free, online toolkit includes maps, interactive tools to generate climate change data visualizations, Taking Action stories from real-world case studies, and the ability to search the entire federal government's climate science domain and filter results according to your interests-and many other resources!

\section{Western Alaska Landscape Conservation Cooperative (LCC)}

\section{https://westernalaskalcc.org/SitePages/Western\%20Alaska\%20LCC.aspx}

The Western Alaska Landscape Conservation Cooperative promotes coordination, dissemination, and development of applied science to inform landscape level conservation, including terrestrial-marine linkages, in the face of landscape scale stressors, focusing on climate change. Their website contains many resources on shoreline change, including webinars, photos, assessments, and more. 


\section{DATASHEETS}

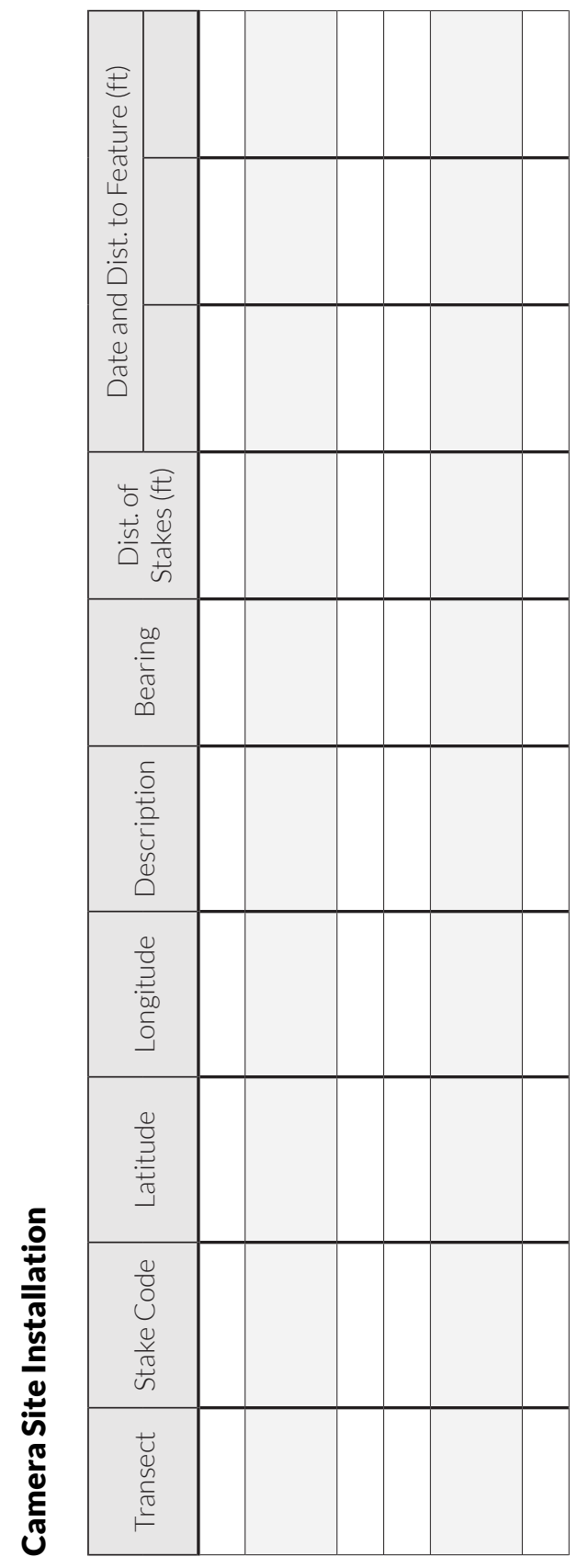




\section{Coastal Shoreline Measurements-Stake Measurement Data Sheet}

Date/Time:

Data Collection Team:

Location:

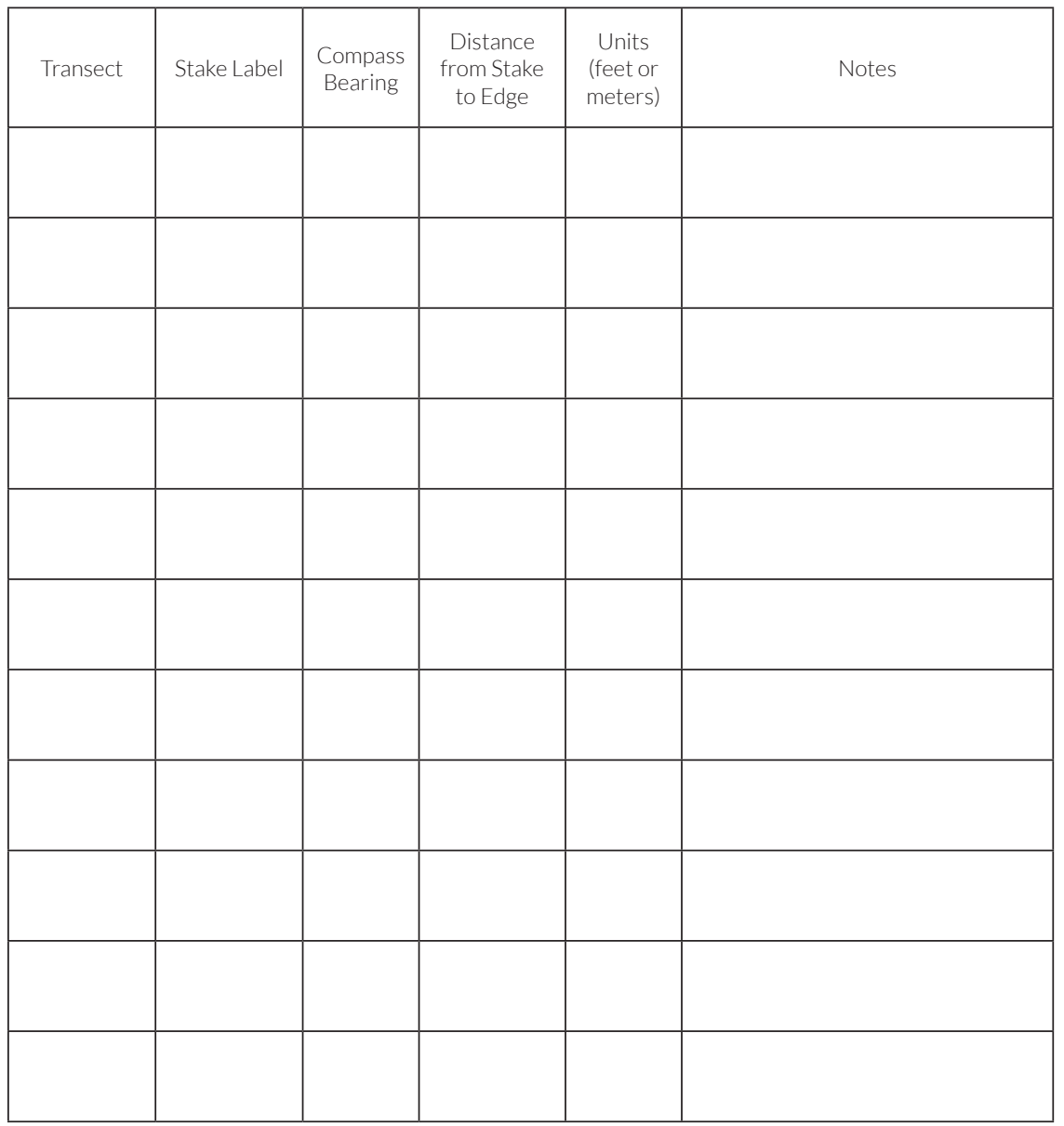

Time at completion:

Comments:

\section{Don't forget to take photographs!}




\section{Coastal Shoreline Measurements-Stake Measurement Data Sheet}

Date/Time:

Data Collection Team:

Location:

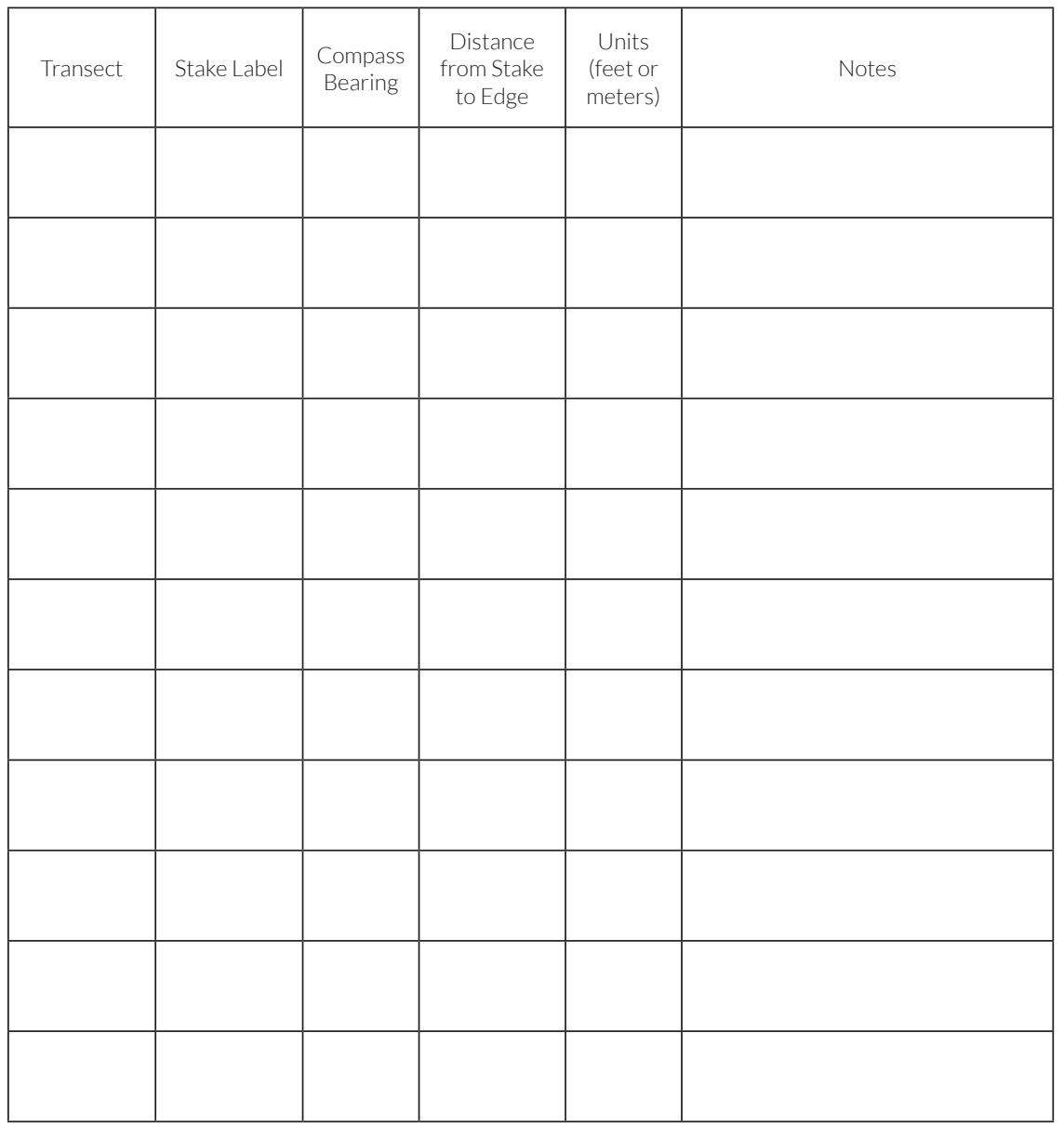

Time at completion:

Comments:

\section{Don't forget to take photographs!}




\section{Coastal Elevation Profile-"Emery Rod" Data Sheet}

Date/Time:

Data Collection Team:

Location:

Compass Bearing:

Time at Start:

\begin{tabular}{|c|c|c|c|}
\hline Segment\# & Spacing & Change in Elevation & Notes \\
\hline & $\square$ fixed or. & $\boldsymbol{Q}$ up $\boldsymbol{\square}$ down & \\
\hline & a fixed or. & $\boldsymbol{Q}$ up $\boldsymbol{\square}$ down & \\
\hline & a fixed or & $\boldsymbol{Q}$ up $\boldsymbol{\square}$ down & \\
\hline & a fixed or & $\boldsymbol{Q}$ up $\boldsymbol{\square}$ down & \\
\hline & a fixed or. & $\boldsymbol{Q}$ up $\boldsymbol{\square}$ down & \\
\hline & a fixed or. & $\boldsymbol{Q}$ up $\boldsymbol{\square}$ down & \\
\hline & $\boldsymbol{Q}$ fixed or & $\boldsymbol{Q}$ up $\boldsymbol{\square}$ down & \\
\hline & a fixed or. & $\boldsymbol{Q}$ up $\boldsymbol{\square}$ down & \\
\hline & $\boldsymbol{Q}$ fixed or & $\boldsymbol{Q}$ up $\boldsymbol{Q}$ down & \\
\hline & $\boldsymbol{Q}$ fixed or & $\boldsymbol{Q}$ up $\boldsymbol{\square}$ down & \\
\hline & $\boldsymbol{Q}$ fixed or & $\boldsymbol{Q}$ up $\boldsymbol{\square}$ down & \\
\hline & a fixed or & $\boldsymbol{Q}$ up $\boldsymbol{Q}$ down & \\
\hline & $\boldsymbol{Q}$ fixed or & $\boldsymbol{Q}$ up $\boldsymbol{\square}$ down & \\
\hline & $\boldsymbol{Q}$ fixed or & $\boldsymbol{Q}$ up $\boldsymbol{\square}$ down & \\
\hline & $\boldsymbol{Q}$ fixed or & $\boldsymbol{Q}$ up $\boldsymbol{\square}$ down & \\
\hline & $\boldsymbol{Q}$ fixed or & $\boldsymbol{Q}$ up $\boldsymbol{\square}$ down & \\
\hline & $\boldsymbol{Q}$ fixed or & $\boldsymbol{Q}$ up $\boldsymbol{\square}$ down & \\
\hline & $\square$ fixed or & $\boldsymbol{Q}$ up $\boldsymbol{\square}$ down & \\
\hline & $\boldsymbol{Q}$ fixed or & $\boldsymbol{Q}$ up $\boldsymbol{\square}$ down & \\
\hline & $\boldsymbol{Q}$ fixed or & $\boldsymbol{Q}$ up $\boldsymbol{\square}$ down & \\
\hline & $\square$ fixed or. & $\boldsymbol{Q}$ up $\boldsymbol{\square}$ down & \\
\hline
\end{tabular}

Time at completion:

Comments:

\section{Don't forget to take photographs!}

Division of Geological \& Geophysical Surveys

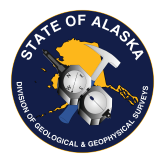




\section{Coastal Elevation Profile-"Emery Rod" Data Sheet}

Date/Time:

Data Collection Team:

Location:

Compass Bearing:

Time at Start:

\begin{tabular}{|c|c|c|c|}
\hline Segment\# & Spacing & Change in Elevation & Notes \\
\hline & $\square$ fixed or. & $\boldsymbol{Q}$ up $\boldsymbol{\square}$ down & \\
\hline & a fixed or. & $\boldsymbol{Q}$ up $\boldsymbol{\square}$ down & \\
\hline & a fixed or & $\boldsymbol{Q}$ up $\boldsymbol{\square}$ down & \\
\hline & a fixed or & $\boldsymbol{Q}$ up $\boldsymbol{\square}$ down & \\
\hline & a fixed or. & $\boldsymbol{Q}$ up $\boldsymbol{\square}$ down & \\
\hline & a fixed or. & $\boldsymbol{Q}$ up $\boldsymbol{\square}$ down & \\
\hline & $\boldsymbol{Q}$ fixed or & $\boldsymbol{Q}$ up $\boldsymbol{\square}$ down & \\
\hline & a fixed or. & $\boldsymbol{Q}$ up $\boldsymbol{\square}$ down & \\
\hline & $\boldsymbol{Q}$ fixed or & $\boldsymbol{Q}$ up $\boldsymbol{Q}$ down & \\
\hline & $\boldsymbol{Q}$ fixed or & $\boldsymbol{Q}$ up $\boldsymbol{\square}$ down & \\
\hline & $\boldsymbol{Q}$ fixed or & $\boldsymbol{Q}$ up $\boldsymbol{\square}$ down & \\
\hline & a fixed or & $\boldsymbol{Q}$ up $\boldsymbol{Q}$ down & \\
\hline & $\boldsymbol{Q}$ fixed or & $\boldsymbol{Q}$ up $\boldsymbol{\square}$ down & \\
\hline & $\boldsymbol{Q}$ fixed or & $\boldsymbol{Q}$ up $\boldsymbol{\square}$ down & \\
\hline & $\boldsymbol{Q}$ fixed or & $\boldsymbol{Q}$ up $\boldsymbol{\square}$ down & \\
\hline & $\boldsymbol{Q}$ fixed or & $\boldsymbol{Q}$ up $\boldsymbol{\square}$ down & \\
\hline & $\boldsymbol{Q}$ fixed or & $\boldsymbol{Q}$ up $\boldsymbol{\square}$ down & \\
\hline & $\square$ fixed or & $\boldsymbol{Q}$ up $\boldsymbol{\square}$ down & \\
\hline & $\boldsymbol{Q}$ fixed or & $\boldsymbol{Q}$ up $\boldsymbol{\square}$ down & \\
\hline & $\boldsymbol{Q}$ fixed or & $\boldsymbol{Q}$ up $\boldsymbol{\square}$ down & \\
\hline & $\square$ fixed or. & $\boldsymbol{Q}$ up $\boldsymbol{\square}$ down & \\
\hline
\end{tabular}

Time at completion:

Comments:

\section{Don't forget to take photographs!}

Division of Geological \& Geophysical Surveys

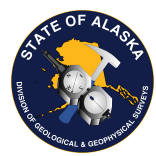




\section{ACKNOWLEDGMENTS}

Photos in this booklet were taken during a two-day workshop in Dillingham, August 2016, and at local site installations in Levelock, Togiak, Port Heiden, Dillingham, Goodnews Bay, and St. Paul Island. Sixteen participants from 13 communities were involved, and allowed the use of their photographs for educational purposes. We thank all of the participants for their involvement and enthusiasm.

This publication is sponsored by the Bureau of Indian Affairs.

This publication is the result of research sponsored by Alaska Sea Grant with funds from the National Oceanic and Atmospheric Administration Office of Sea Grant, Department of Commerce, under grant no. NA14OAR4170079 (project no. R/127-01), and from the University of Alaska with funds appropriated by the state.

\section{AUTHOR CONTACT INFORMATION}

\section{Jacquelyn Overbeck}

Coastal Hazards Program Manager

Alaska Department of Natural Resources

Division of Geological \& Geophysical Surveys

(907) 451-5026

jacquelyn.overbeck@alaska.gov

\section{Richard Buzard}

NOAA Digital Coast Fellow

Alaska Department of Natural Resources

Division of Geological \& Geophysical Surveys

richard.buzard@alaska.gov

\section{Chris Maio}

Arctic Coastal Geoscience Lab University of Alaska Fairbanks Department of Geosciences

(907) 474-5651

\section{cvmaio@alaska.edu}

